Marquette University Law School

Marquette Law Scholarly Commons

Faculty Publications

Faculty Scholarship

$1-1-2010$

\title{
"Sports Law": Implications for the Development of International, Comparative, and National Law and Global Dispute Resolution
}

Matthew J. Mitten

Marquette UniversityLaw School, matt.mitten@marquette.edu

Hayden Opie

Follow this and additional works at: http://scholarship.law.marquette.edu/facpub

Part of the Law Commons

Publication Information

Matthew J. Mitten \& Hayden Opie, “Sports Law”: Implications for the Development of

International, Comparative, and National Law and Global Dispute Resolution, 85 Tul. L. Rev. 269

(2010) (C) Matthew J. Mitten and Hayden Opie

\section{Repository Citation}

Mitten, Matthew J. and Opie, Hayden, "“Sports Law": Implications for the Development of International, Comparative, and National Law and Global Dispute Resolution" (2010). Faculty Publications. Paper 519.

http://scholarship.law.marquette.edu/facpub/519

This Article is brought to you for free and open access by the Faculty Scholarship at Marquette Law Scholarly Commons. It has been accepted for inclusion in Faculty Publications by an authorized administrator of Marquette Law Scholarly Commons. For more information, please contact

megan.obrien@marquette.edu. 


\title{
TULANE \\ LAW REVIEW
}

\begin{tabular}{lll}
\hline VOL. 85 & DECEMBER 2010 \\
\hline
\end{tabular}

\section{"Sports Law": \\ Implications for the Development of International, Comparative, and National Law and Global Dispute Resolution}

\author{
Matthew J. Mitten* \\ Hayden Opie ${ }^{\dagger}$
}

In this Article, we observe that legal regulation of national and international sports competition has become extremely complex and has entered a new era, which provides fertile ground for the creation and evolution of broader legal jurisprudence with potentially widespread influence and application. Our principal aim is to draw these developments to the attention of legal scholars and attorneys not necessarily familiar with sports law. Specifically, the evolving law of sports is having a significant influence on the development of international and national laws, is establishing a body of substantive legal doctrine ripe for analysis from a comparative law perspective, and has important implications for global dispute resolution. For example, the global processes used to establish an international sports antidoping code and to resolve a broad range of Olympic and international sports disputes (which is rapidly creating a body of global private law) provide paradigms of international cooperation and global lawmaking. In addition, judicial resolution of sports-related cases may develop jurisprudence with new applications and

(C) 2010 Matthew J. Mitten and Hayden Opie.

Professor of Law and Director, National Sports Law Institute and LL.M. in Sports Law Program for Foreign Lawyers, Marquette University Law School; Member, Court of Arbitration for Sport, Lausanne, Switzerland.

$\dagger$ Director of Studies, Sports Law Program, Melbourne Law School, The University of Melbourne, Australia; Foundation President and Life Member of the Australian and New Zealand Sports Law Association.

The authors thank Margareta Baddeley, John Barnes, Timothy Davis, Dr. Michelle Gallen, Rick Karcher, Robert Macdonald, Jim Nafziger, Michael M. O'Hear, Andrew Vaitiekunas, and Maureen Weston for their review of earlier drafts of the Article and insightful comments. The authors also are grateful to Nick Rieder, Marquette University Law School Class of 2010, for his research assistance. 
influence. Our objective is to generate greater awareness of the importance of sports, not only as a worldwide cultural phenomenon and a significant part of the twenty-first-century global economy, but as a rich source of international and national public and private laws that provide models for establishing, implementing, and enforcing global legal norms.

I. INTRODUCTION

II. INTERNATIONAL SPORTS ANTIDOPING LAW: A MODEL FOR

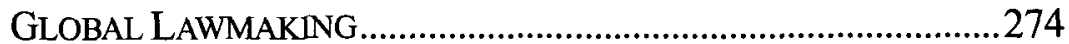

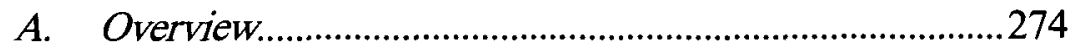

B. A Brief Review of Antidoping Measures to the Late 1990 s......

C. Twenty-First-Century World Antidoping Regime Evolves into International Legal System.

III. "LEX SPORTIVA": LESSONS FOR GLOBAL DISPUTE RESOLUTION AND THE CREATION OF INTERNATIONAL LEGAL NORMS

A. Adjudication of Olympic and International Sports Disputes: The Need for a Specialized International Tribunal.

B. Court of Arbitration for Sport (CAS)..................................285

C. CAS: A Fertile Ground for Academic Study ...................288

IV. INTERNATIONAL SPORTS LAW, A FORM OF GLOBAL LEGAL PLURALISM, AND PROSPECTS FOR DISPLACING NATIONAL LAW

A. Evolving Judicial Treatment of International Sports Agreements and Rules: Traditional vs. Deferential Approach.

B. CAS Awards, Lex Sportiva, and the Displacement of National Law.

V. SPORTS AS A HARBINGER OF FUTURE NATIONAL AND INTERNATIONAL LAW AND A FORUM FOR PUBLIC POLICY DEBATE

A. Domestic Sports Law's Influence on the Development of General National Laws and Public Policy.

B. International Sports Law's Influence on the

Development of Global Legal Norms and Policies

1. Intellectual Property and Anti-ambush Marketing Laws

2. Human Rights Laws

VI. CONCLUSION 


\section{INTRODUCTION}

This Article is written primarily for legal academics whose teaching and scholarship does not focus on sports law, as well as lawyers and judges unfamiliar with the subject. Our purpose is not to provide an introduction, overview, or primer to sports law. ${ }^{1}$ Rather, it is to alert others to the potential of sports as a driver of legal change and to encourage participation in the development of sports law by a wide range of lawyers as an integral part of their diverse professional and scholastic pursuits.

Legal regulation of national and international sports competition has become extremely complex and has entered a new era. Its study requires consideration of multiple areas of law (which may be conflicting) and an interdisciplinary perspective. ${ }^{2}$ This new era of sports regulation provides fertile ground for the creation and evolution of jurisprudence with potentially widespread influence and application. However, significant legal developments originating in sport often are not recognized - much less carefully analyzed — by academics other than a relatively small group of sports law professors. Because of their broad implications for the development of law and public policy in other areas, particularly international and comparative law, as well as global dispute resolution, it is important that legal scholars, attorneys, and judges be aware of and carefully consider sports-related legal developments.

Despite the fact that virtually all areas of law (individually and in combination) regulate sports competition (including broad, important areas such as antitrust, contract, intellectual property, and labor law), relatively few academics teach a sports law course or are sports law scholars. $^{3}$ Although sports-related cases are well represented among landmark decisions in many areas of law and export important legal principles into jurisprudence with broader application, ${ }^{4}$ academic study

1. Such a purpose may be achieved for United States and Australian law respectively by consideration of WALTER T. CHAMPION, SPORTS LAW IN A NUTSHELL (4th ed. 2009); DEBORAH HEALEY, SPORT AND THE LAW (3d ed. 2005).

2. See generally MaTtheW J. MitTEN ET AL., SPORTS LAW AND REgUlation: CASES, MATERials, AND Problems 1-21 (2d ed. 2009).

3. According to the 2009-2010 Association of American Law Schools Directory of Law Teachers, there are only 120 professors who teach sports law, while there are approximately 340 antitrust law, 1800 constitutional law, and 360 labor law professors. Antitrust, constitutional, and labor law are three of the most significant areas of public law that regulate sports in the United States. ASS'N OF AM. LAW SCH., 2009-2010 DIRECTORY OF LAW TEACHERS (2009-2010).

4. See generally Daniel E. Lazaroff, The Influence of Sports Law on American Jurisprudence, 1 VA. SPORTS \& ENT. L.J. 1 (2001); Charles Yablon, On the Contribution of 
of the law regulating sports is relatively new. ${ }^{5}$ In fact, there is no consensus among scholars who regularly study the rapidly developing body of law that governs the sports industries whether "sports law" is a separate body of law or merely the application of general laws more properly termed "law and sports." Nevertheless, regardless of the nomenclature used, "sports law" has a legitimate place in a law school curriculum because of its challenging legal issues, multidisciplinary aspects, and practical relevance to a large sector of society, as well as the significant student interest which it generates.

Baseball to American Legal Theory, 104 YALE L.J. 227 (1994). A number of the landmark rulings of the High Court of Australia have occurred in the context of sporting activity. See, e.g., Wyong Shire Council v Shirt (1980) 146 CLR 40 (Austl.) (discussing the standard of care in the tort of negligence and holding that signage incorrectly identifying "deep water" caused water-skiing accident on lake); R v Judges of the Fed. Court Austl.; Ex parte W. Austl. Nat'l Football League Inc. (1979) 143 CLR 190 (Austl.) (discussing the meaning of federal corporations power conferred by the Australian Constitution $\mathrm{s} 51(\mathrm{xx})$ and holding that professional football clubs are trading corporations); Victoria Park Racing \& Recreation Grounds Co. v Taylor (1937) 58 CLR 479 (Austl.) (discussing the nature of property and holding that a horse-racing track had no rights to an event and was therefore unable to prevent radio calls of races originating from a structure overlooking the track). The late Edward Grayson, widely recognized as "the father" of English sports law, wrote in 1993 about the peculiar ability of sports to raise novel legal issues on which high appellate courts could differ. He illustrated this proposition by reference to seven decisions of the Court of Appeal on sports, which had been overruled on further appeal to the House of Lords. Edward Grayson, Getting the Right Result, 143 NEw L.J. 61 (1993).

5. The first treatises on sports law in both the United States and Australia were not published until the late 1970s and 1980s. See, e.g., G.M. Kelly, SpORT AND THE LAW: AN Australian PERSPECTIVE (1987); GEORGE W. ShUBERT ET AL., SPORTS LAW (1986); LIONEL S. SOBEL, PROFESSIONAL SPORTS AND THE LAW (1977); JoHN C. WeistarT \& CYM H. LOWELL, THE LAW OF SPORTS (1979). The first U.S. sports law casebook (RAY YASSER ET AL., SPORTS LAW: CASES AND MATERIALS (1990)) was not published until twenty years ago. The first Canadian treatise was published in 1983. JOHN BARNES, SPORTS AND THE LAW IN CANADA (1st ed. 1983). Neither author of this Article took a sports law course during study for his first law degree. Similarly, the academic study of sports law in leading European countries such as Switzerland, Great Britain, Germany, France, and Italy did not gain real momentum until the early 1990s, although there are earlier treatises. See, e.g., EDWARD GRAYSON, SPORT

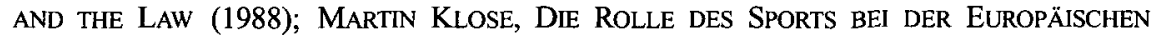
Einigung (1989); Alberto M. Toro \& Piergiovanni CANEPEle, Codice Dello Sport (Dott A. Giuffrè ed., 1980).

6. For an overview of this debate about the nature of sports law and whether the area displays the unique and coherent characteristics of a discreet body of law or is one where principles from more settled legal disciplines are found to have particular applications, see generally SimON GARDINER ET AL., SPORTS LAW 37-93 (3d ed. 2006); Timothy Davis, What Is Sports Law?, 11 MARQ. Sports L. Rev. 211 (2001); see also LaRS HALGREen, EUROPEAN SPORTS LAW: A COMPARATIVE ANALYSIS OF THE EUROPEAN AND AMERICAN MODELS OF SPORT 23-32 (2004) (suggesting a framework for determining the content of sports law).

7. Some U.S. (e.g., Marquette University Law School, Florida Coastal School of Law, and Tulane University Law School) and Australian (e.g., Melbourne Law School) law schools now offer very popular specialized programs of study in sports law as part of their J.D. and/or LL.M. curriculums. 
This Article's primary objective, however, is not to interest more law professors in teaching sports law, using sports examples to aid their teaching in other courses, or becoming sports law scholars (although it may have some or all of those effects). ${ }^{8}$ Nor is this discussion targeted at academics already having a keen interest in sports law. Rather, this Article is addressed to a wider audience of legal scholars. We believe that the evolving law of sports is having and will continue to have a significant influence on, and implications for, the development of broader international and national laws (e.g., intellectual property and human rights laws) and provides a rich source of substantive legal doctrine for analysis from a comparative law perspective. Moreover, the global processes used to establish an international sports antidoping code and to resolve Olympic and

8. Sports provide many illustrations and examples that can be used to facilitate classroom teaching and learning, including usage by law professors to enhance student understanding of other legal doctrines. For example, cricket and goaltending can be used to teach cause-in-fact doctrine in tort and criminal law. See David Fraser, CRICKET AND the LAW: THE MAN IN WHITE IS ALWAYS Right 125-32 (2005).

Sports also may be used to enliven a drowsy class by mentioning a judicial opinion or fact scenario involving a sports-related incident or a celebrity athlete. Sport is a setting in which judges can be carried away (or least depart from their aura of stateliness) much to the entertainment of students and observers. In Zhu $v$ Treasurer of New South Wales, a case concerning the tort of inducing breach of contract, the High Court of Australia in a joint judgment observed in the opening sentence:

It is a truth almost universally acknowledged - a truth unpatriotic to question-that the period from 15 September 2000 to 1 October 2000, when the Olympic Games were held in Sydney, was one of the happiest in the history of that city. The evidence in this case, however, reveals that the preparations for that event had a darker side.

(2004) 218 CLR 530, 535 (Austl.). Regarding American jurisprudence, one author stated:

There was something about baseball that turned cerebral judges into pennantwaving schoolboys; that caused them to lose their judicial bearings, to twist precedents, and to jeopardize the dignity of the federal courts; and that made it nearly impossible for any litigant to defeat the baseball establishment. This case was about more than Federal Baseball and Toolson or Justice Holmes and stare decisis; it was about the grip of the national pastime on the minds of the men in black robes. This was what Flood was up against as his lawsuit made its way to the Supreme Court.

Brad Snyder, A Well-Paid Slave: CuRt Flood's Fight for Free Agency in PROFESSIONAL SPORTS 223 (2006). To use Barry Bonds as another example, several legal issues have arisen: (1) whether his career home run total should be recognized as MLB's alltime record in light of allegations he used and lied about banned performance-enhancing substances, (2) ownership of the baseball Bonds hit that broke Hank Aaron's career home run record, and (3) the application of federal constitutional law to governmental seizure of confidential electronic records evidencing his positive test for banned performanceenhancing substances. See generally Mark Fainaru-Wada \& Lance Williams, The Truth About Barty Bonds and Steroids, SPORTS ILLUSTRATED, Mar. 13, 2006, http://sportsillustrated. cnn.com/vault/article/magazine/MAG1116081/index.htm. 
international sports provide paradigms of international cooperation between private parties and governments and lawmaking as well as effective and respected global dispute resolution. We suggest that awareness of and participation in sports law debates and developments have become unavoidable dimensions to the pursuit of scholarship in a growing number of other fields.

To illustrate our thesis, we have identified four significant sports law developments and themes, which we will describe, analyze, and explain why each one merits academic study. First, international sports antidoping rules, especially the World Anti-Doping Code (WADA Code), provide a paradigm for rapidly creating and implementing globally accepted legal norms and an example of an international legal system. Second, the process by which "lex sportiva," a developing body of international sports law based largely on private agreements and dispute resolution processes, is being created by the Court of Arbitration for Sport and becoming globally accepted has wide-ranging implications for global dispute resolution and the establishment of international legal norms. Third the emerging propensity of private agreements between international sports governing federations, a form of global legal pluralism, to displace national laws raises important issues regarding national sovereignty. And fourth, judicial resolution of sports-related disputes and sports-specific legislation may foreshadow how more general national and international laws will develop and/or how broader public policy issues will be resolved.

\section{INTERNATIONAL SPORTS ANTIDOPING LAW: A MODEL FOR GLOBAL LAWMAKING}

\section{A. Overview}

International antidoping measures in sport form an impressive system of global law and regulation. This system is notable because of its large scale and rapid establishment. Other less readily apparent but nonetheless significant features include a successful international partnering of private and governmental bodies, the very high degree of compliance achieved in enforcement of the penalties meted out for breaches of antidoping rules, and the ways in which some controversial issues of human rights have been addressed. 
The centerpiece of the antidoping system is the International Convention Against Doping in Sport. ${ }^{9}$ Adopted by the United Nations Educational, Scientific and Cultural Organization (UNESCO), the Convention opened for signature on October 19, 2005, and became effective on February 1, 2007. As of December 7, 2009, the Convention had 130 State Parties. ${ }^{10}$ The Convention is intended to commit States domestically and at the international level to "the fight against doping in sport" and obligates signatories to "adopt appropriate measures" which "may include legislation, regulation, policies or administrative practices." While the creation of this treaty obligation correctly implies that significant legal and regulatory work is necessary to combat sports doping effectively, the Convention is the culmination of an immense effort led by the International Olympic Committee (IOC), the "supreme authority" of the Olympic Movement, to develop a harmonized, worldwide set of laws and rules against sports doping. ${ }^{12}$ A doping scandal surrounding the 1998 Tour de France cycling race spurred a worldwide effort to eradicate sports doping, which in a period of less than a decade, resulted in the following significant events leading to the adoption of the

9. International Convention Against Doping in Sport, U.N. EDUC., SCIENTIFIC \& CULTURAL ORG. (UNESCO) (Oct. 19, 2005), http://unesdoc.unesco.org/images/0014/0014 25/142594m.pdf\#page $=2$ [hereinafter International Convention].

10. Australia and the United States of America ratified the Convention on January 17, 2006, and August 25, 2008, respectively. See List of State Parties, UNESCO, http://portal. unesco.org/la/convention.asp? $\mathrm{KO}=31037$ \&language $=\mathrm{E}$ (last visited Nov. 6, 2010).

11. International Convention, supra note 9, arts. 1, 5. However, under the laws of both Australia and the United States, the Convention is not "self-executing" in the sense of automatically becoming enforceable domestic law. As a general proposition, federal domestic legislation is required. See generally Medellin v. Texas, 552 U.S. 491 (2008); Richardson v Forestry Comm'n (1988) 164 CLR 261 (Austl.). Following ratification and in order to comply with the Convention, Australia replaced its antidoping legislation with the Australian Sports Anti-Doping Authority Act 2006 (Cth). Rather than compelling domestic sports leagues and governing bodies to comply with the WADA Code, the Australian government's policy has been to (successfully) exert pressure by means of adverse publicity and threatened withdrawal of financial support. Thus far, the United States Congress has not enacted enabling legislation. Even if it were to do so, the flexible terms of article 5 of the Convention would not require Congress to compel U.S. professional sports leagues and governing bodies to comply with the WADA Code.

12. The modern Olympic Movement consists of those "organisations, athletes and other persons who agree to be guided by the principles of the Olympic Charter." The Organisation, OLYMPIC MOVEMENT, http://www.olympic.org/en/content/The-IOC/The-IOCInstitution $1 / ? \mathrm{Tab}=1$ (last visited Nov. 6, 2010). There are numerous organizations and persons that are part of the Olympic Movement, including the IOC, International Sports Federations (IFs) (the international governing bodies for each Olympic sport), National Olympic Committees (NOCs), National Governing Bodies (NGBs) for each Olympic sport, the World Anti-Doping Agency, the Court of Arbitration for Sport, and the Olympic Museum, as well as millions of individual athletes, judges, and coaches. 
Convention. ${ }^{13}$ These included the 1999 establishment of the World Anti-Doping Agency (WADA), a private international organization whose mission is to coordinate, monitor, and promote the worldwide fight against doping in sport, as a joint effort of the Olympic Movement and national governments; the making of the March 2003 Copenhagen Declaration on Anti-Doping in Sport, which evinced an international commitment to develop and implement worldwide antidoping rules; $;{ }^{14}$ and the promulgation of the WADA Code, ${ }^{15}$ which became effective on January 1, 2004, and established a model for international and national sports antidoping policies and practices. ${ }^{16}$

\section{B. A Brief Review of Antidoping Measures to the Late 1990s}

Doping (described briefly as the use of chemical substances and certain other artificial methods to enhance athletic performance) is not new in sport. ${ }^{17}$ The principal arguments against doping have concerned the need to prevent cheating by athletes and adverse effects on their health. ${ }^{18}$ At the Olympic level, doping was condemned by the IOC in 1938. It resolved that any person "accepting or offering to

13. See Willy Voet, Breaking the Chan: Drugs and Cycling: The True Story (William Fotheringham trans., 2d ed. 2002). On July 8, 1998, Voet was stopped by customs officials on the Franco-Belgian border. He was the soigneur (trainer) for the Festina cycling team competing in the Tour de France. A search of his car produced various sophisticated performance-enhancing drugs and doping equipment. Voet was arrested, briefly imprisoned, and eventually convicted of various offenses against French law relating to supplying and inciting the use of drugs. Along with other team management and support staff, he received a suspended jail sentence and was fined.

14. There are 193 national governments that are signatories to the Declaration. List of Signatories, WORLD ANTI-DOPING AGENCY, http:/www.wada-ama.org/en/World-Anti-DopingProgram/Governments/Copenhagen-Declaration-on-Anti-Doping-in-Sport/List-of-signatories/ (last visited Nov. 6, 2010).

15. For the current edition of the WADA Code (effective Jan. 1, 2009), see World Anti-Doping Code, WORLD ANTI-DOPING AGENCY, http://www.wada-ama.org/Documents/ World_Anti-Doping_Program/WADP-The-Code/WADA_Anti-Doping_CODE_2009_EN.pdf (last visited Nov. 6, 2010) [hereinafter WADA Code].

16. For a brief account from an insider, see RICHARD W. POUND, INSIDE DOPE 91-104 (2006).

17. See, e.g., TOM DONOHOE \& NeIL JOHNSON, FOUl PlaY: Drug ABuSE IN SPORTS 24 (1986); BarRIE Houlmhan, DyING To WIN: DopING IN SPORT AND THE DEvelopment OF ANTI-DoPING POLICY 33-34 (1999); Michele Verroken, Drug Use and Abuse in Sport, in DRUGS IN SPORT 18-19 (David R. Mottram ed., 2d ed. 1996).

18. However, it has been claimed controversially that these arguments are of relatively recent origin and that doping was largely tolerated if not accepted for significant periods of time. See Paul Dimeo, A History of DrUg Use IN SPORT 1876-1976: BeYond GOOd AND EVIL (2007). But see ALBERT DiRIX \& XAVIER STURBOIS, THE FIRST THIRTY YeARS OF THE INTERNATIONAL OLYMPIC COMMITTEE MEDICAL COMMISSION, 1967-1997, at 13, 16 (1999); K. Fitch, A History of Drug Use in Sport 1876-1976: Beyond Good and Evil, 42 BRIT. J. OF SPORTS MED. 76 (2008) (book review). 
supply dope" was to be excluded from the Olympic Games and amateur sports meetings. ${ }^{19}$ In the postwar years, concerns over doping grew. $^{20}$ The deaths of some cyclists from suspected drug use in the 1960s were influential in the IOC establishing a medical commission charged with the task of controlling doping. ${ }^{21}$ Prohibition of and testing for specific drugs commenced in 1968 at both the Games of the Olympiad (Mexico City) and Winter Olympic Games (Grenoble). ${ }^{22}$

In the years that followed, antidoping measures expanded in response to the emergence of new forms of doping and a growing interest in and understanding of the nature of the problem. Some key features of this expansion included growth in the number of sports and events subject to doping controls, the development of reliable scientific techniques for the detection of prohibited substances ${ }^{23}$ and methods, ${ }^{24}$ the accreditation of testing laboratories by the $\mathrm{IOC}_{2}{ }^{25}$ the introduction of out-of-competition testing ${ }^{26}$ and increased reporting (often in sensational terms) in the news media of incidents of doping. ${ }^{27}$ The

19. DiRIX \& STURBOIS, supra note 18 , at 14 . It should be noted that while the IOC had power to act in respect of the Olympic Games, it could not make rules of direct application in relation to the activities of other bodies. Also, chemical testing was not introduced for around another thirty years.

20. Reports were received of "obvious signs of the reckless use of medicinal substances" at the Helsinki (1952) and Melbourne (1956) Olympic Games. Id. at 13. There is an earlier report of post-World War II drug use from the London Olympic Games in 1948. DIMEO, supra note 18 , at 54 .

21. The death of a cyclist at the Rome Olympic Games was allegedly the result of the use of amphetamines. DiRIX \& STURBOIS, supra note 18, at 13. However, this cause of death has been vigorously contested. Verner Møller, Knud Enemark Jensen's Death During the 1960 Rome Olympics: A Search for Truth?, 25 SPORT IN HIST. 452 (2005). Shortly afterwards in 1961, the IOC established a Medical Commission, and at the 1964 Olympic Games in Tokyo, attempts were made to test cyclists for doping, but this led to a boycott. The death of the British cyclist Tommy Smith in 1967 prompted the reconstitution of the Medical Commission into its modern-day form. DIRIX \& STURBoIs, supra note 18, at 13-14.

22. This was conducted by way of analysis of a sample of an athlete's urine and this remains the principal method today.

23. See, e.g., Michele Verroken \& David R. Mottram, Doping Control in Sport, in DRUGS IN SPORT 235 (David R. Mottram ed., 2d ed. 1996).

24. Prohibitions were extended to include methods of doping such as "blood doping" and attempts to foil reliable testing ranging from refusing to provide urine samples for testing to the substitution of "clean" urine.

25. Verroken \& Mottram, supra note 23, at 239-41; DiRIX \& STURBOIS, supra note 18, at 33-34.

26. Out-of-competition testing was introduced as a response initially to anabolic steroids, which could deliver lasting performance-enhancing effects but be cleared from an athlete's body well before competition day. Verroken \& Mottram, supra note 23, at 238.

27. Perhaps the most notorious incident was the disqualification of Canadian runner, Ben Johnson, from the men's 100-meter sprint at the Seoul Olympic Games in 1988.

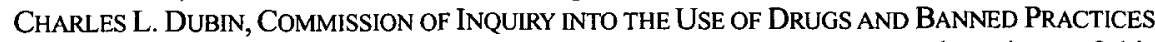
INTENDED To InCREASe ATHLetic PeRformanCe 234-309 (1990). For other views of this 
importance and increasing complexity of antidoping rules attracted the attention of national governments. In turn, this led to judicial ${ }^{28}$ and parliamentary ${ }^{29}$ inquiries, domestic legislation prohibiting doping, ${ }^{30}$ dedicated antidoping agencies, ${ }^{31}$ and international treaties ${ }^{32}$ and arrangements. ${ }^{33}$

Despite this activity, antidoping efforts were seriously balkanized, possibly compromised, and faced major shortcomings by the mid to late 1990s. This was largely because of differences in approach among sports and across national legal systems as well as the circumstance that not all sports and competitions were affiliated with the Olympic Movement. Although the IOC had provided significant leadership, there was no uniform list of prohibited substances and methods worldwide. Some sports had no antidoping rules whatsoever. Furthermore, concerns were widespread that some states and sports paid lip service to the antidoping cause while systematically pursuing doping practices or shielding transgressing athletes from the full weight of disciplinary processes by displaying "hometown" favoritism. ${ }^{34}$

incident, see Charlie francis with JefF Coplon, Speed TraP: Inside the Biggest SCANDAL IN OLYMPIC HISTORY (1990); VYV SIMSON \& ANDREW JENNINGS, THE LORDS OF THE RINGS: POWER, MONEY AND DRUGS IN THE MODERN OLYMPICS 195-200 (1992).

28. See generally DUBIN, supra note 27.

29. See, e.g., The Parliament of the Commonwealth of Austl., Drugs in Sport: AN INTERIM REPORT OF THE SENATE STANDING COMMITTEE ON ENVIRONMENT, RECREATION AND THE ARTS (1989); THE PARLIAMENT OF THE COMMONWEALTH OF AUSTL., DRUGS IN SPORT: SECOND REPORT OF THE SENATE STANDING COMMITTEE ON ENVIRONMENT, RECREATION AND THE ARTS (1990).

30. For example, Portugal: Anti-Doping Regulation, Decreto-Lei No. 374/79, de 8 de Setembro de 1979, DiÁRIO DE RepúBlica de 8.9.1979 (Port.); France: Loi 89-432 du 28 juin 1989 relative à la prévention et à la répression de l'usage des produits dopants à l'occasion des compétitions et manifestations sportives [Law 89-432 of June 28, 1989 for the prevention and punishment of the use of doping agents at sporting competitions and events], Journal OfFiciel de La République FranÇaise [J.O.] [OFFICIAL GAZETTE OF FranCE], July 1,1989 , p. 8146.

31. Among the first, if not the first, was the Australian Sports Drug Agency established by the Australian Sports Drug Agency Act 1990 (Cth).

32. See, e.g., Council of Europe, Anti-Doping Convention, opened for signature Nov. 16, 1989, C.E.T.S. No. 135 (entered into force Mar. 1, 1990).

33. See, for example, International Anti-Doping Arrangement 1997 (IADA), which was a multilateral agreement between Australia, Canada, Denmark, Finland, the Netherlands, New Zealand, Norway, South Africa, Sweden, and the United Kingdom. The member countries in IADA worked to establish international standards of antidoping practice. About $I A D A$, IADA, http://www.iada.rf.se/t2aspx?p=105084 (last visited Nov. 12, 2010).

34. The astonishingly evil practices of the former German Democratic Republic (East Germany) in regard to doping its athletes in the pursuit of political agendas was coming to light. STEVEN UNGERLEIDER, FAUST'S GOLD: INSIDE THE EAST GERMAN DOPING MACHINE (2001); Werner W. Franke \& Brigitte Berendonk, Hormonal Doping and Androgenization of Athletes: A Secret Program of the German Democratic Republic Government, 43 ClINICAL CHEMISTRY 1262 (1997). It was feared that this practice had spread to female Chinese 
At the center of this somewhat fractured antidoping system rested a number of key legal disputes. In particular, there was disagreement regarding how to define the elements of doping offenses (especially the requisite fault or intent and defenses). The behavior required to commit a doping offense had become more tightly defined but there was vigorous disagreement over allowing athletes to avoid responsibility because of "exceptional circumstances," such as an absence of knowledge of the prohibition of a substance or absence of knowledge of the presence of a prohibited substance in ingested medicine, food, supplements, or drinks. ${ }^{35}$ There was also significant divergence on the issue of penalties (both as to length and whether discretion should be granted to the sentencing authority). Most significantly, seemingly inconsistent rulings by national courts on the enforceability of lengthy suspensions resulted in an uncertain environment for the development of an internationally coherent approach. $^{36}$

swimmers in particular, but whether doping in Chinese sport was state sponsored has been hotly debated. For commentary on doping and doping scandals in China, see DONG JINXIA, WOMEn, SPORT AND SOCIETY IN MODERn ChINA (2003); David Galluzzi, The Doping Crisis in International Athletic Competition: Lessons from the Chinese Doping Scandal in Women's Swimming, 10 SeTON Hall J. SPORT L. 65 (2000); and Bruce Kidd, Robert Edelman \& Susan Brownell, Comparative Analysis of Doping Scandals: Canada, Russia and China, in Doping In Elite Sport: The Politics of Drugs in the Olympic Movement 153 (Wayne Wilson \& Edward Derse eds., 2001). USA Track and Field (USATF) received strong international criticism for not reporting alleged breaches of doping rules to the governing international federation. "[A]t least thirteen [elite] athletes" who were ultimately "cleared" were involved. See, e.g., PouND, supra note 16, at 96. The USATF cited due process and privacy reasons for refusing to make disclosures unless and until guilt was found. However, critics accused the USATF of favoring its own athletes because by adopting a "secretive" approach it circumvented the international rules, which provided for immediate interim suspension pending the outcome of disciplinary proceedings. Ultimately, the USATF was cleared of any wrongdoing by the CAS, which concluded that the USATF had not acted contrary to the rules of the governing international federation. Arbitration CAS 2002/O/401, Int'l Ass'n of Athletics Fed'ns v. USA Track \& Field, award of Jan. 10, 2003, in DigeST OF CAS AWARDS III 2001-2003, at 37 (Matthieu Reeb ed., 2004); see also Travis T. Tygart, Winners Never Dope and Finally, Dopers Never Win: USADA Takes over Drug Testing of United States Olympic Athletes, 1 DEPAUL J. SPORTS L. CONTEMP. PROBS. 124, 126 (2003).

35. See, e.g., LaURI TaRasti, Legal Solutions IN INTERnational Doping CaSes: AWARDS BY THE IAAF ARBITRATION PANEL 1985-1999 (2000).

36. See, e.g., Edwards v. British Athletic Fed'n, [1997] Eur. L.R. 721 (Ch.) (Eng.) (holding that a four-year ban for a first offense was reasonable and proportional by English High Court); Johnson v. Athletics Can. (1998) 114 O.A.C. 388 (Ont. C.A.) (holding that a life ban for a second offense was not an unreasonable restraint on trade by the Ontario Court of Appeal); Krabbe v Int'l Amateur Athletic Fed'n, Landgericht München I [LGM] [Munich Region Court] May 17, 1995, 4 ZEITSCHRIFT FÜR SPORT UND RECHT [SPURT] 161, 166, 1995 (Ger.) decision of the Munich Region Court of 17 Mar. 1995, SPURT 161, 166 (1995) (establishing that a two-year suspension is the maximum permissible in Germany under fundamental rights and democratic principles). Affirmed by decision of the Munich Region 


\section{Twenty-First-Century World Antidoping Regime Evolves into International Legal System}

Viewed in this historical context, the past decade has been one of momentous development in the international fight against sports doping. Built on the foundations provided by WADA, the Copenhagen Declaration, the WADA Code, and the UNESCO Convention, a tightly knit and, with few exceptions, comprehensive worldwide system now regulates international and Olympic sports' antidoping efforts. The IOC and all international sports federations (IFs), the worldwide governing bodies for each Olympic sport, have adopted antidoping rules that are "WADA Code compliant."37 The national governing bodies (NGBs) for each sport affiliated with the corresponding IF have acted similarly. ${ }^{38}$ Many national sports governing bodies independent of the Olympic Movement have either voluntarily, or under public and governmental pressure, adopted the model established by the WADA Code as the basis of their respective antidoping codes. ${ }^{39}$

The second edition of the WADA Code, which became effective on January 1, 2009, is a relatively brief document of twenty-five articles. It defines various doping offenses (termed "rule violations"), ${ }^{40}$ establishes procedures for collecting and testing samples provided by athletes, ${ }^{41}$ sets minimum standards of due process, ${ }^{42}$ prescribes penalties, ${ }^{43}$ and regulates appeals. ${ }^{44}$ Additionally, the WADA

Court of Appeal. Oberlandesgericht München [OLG M] [Munich Region Court of Appeal] Mar. 28, 1996, ZEITSCHRIFT FÜR SPORT UND RECHT [SPURT] 133, 138, 1996 (Ger.) (holding that a three-year ban was excessive and disproportionate for a first doping offense). See generally Gabrielle Kaufman-Kohler, Antonio Rigozzi \& Giorgio Malinverni, Legal Opinion on the Conformity of Certain Provisions of the Draft World Anti-Doping Code with Commonly Accepted Principles of International Law, WADA-AMA.ORG, paras. 160-161 (Feb. 26, 2003), http://www.wada-ama.org/rtecontent/document/kaufmann-kohler-full.pdf.

37. Rule $\mathbf{4 4}$ of the Olympic Charter stipulates that the "World Anti-Doping Code is mandatory for the whole Olympic Movement," and Rule 26 stipulates that recognition of an IF by the IOC is dependent upon the IF adopting and implementing the WADA Code. Olympic Charter, rules 26, 44 (amended Feb. 11, 2010), http://www.olympic.org/Documents/ olympic_charter_en.pdf (last visited Nov. 8, 2010).

38. See MITTEN ET AL., supra note 2, at 278-80.

39. Thus far, U.S. professional sports leagues such as the National Football League, National Basketball Association, National Hockey League, and Major League Baseball (whose respective drug testing programs are collectively bargained because their players have unionized) and the National Collegiate Athletic Association (which has unilaterally promulgated a separate drug testing policy for its more than 400,000 student-athletes) are notable exceptions.

40. WADA Code, supra note 15, arts. 1-4.

41. Id. arts. 5-6.

42. Id. arts. $7-8$.

43. Id. arts. 9-12. 
Code specifies the roles and responsibilities of all major stakeholders ${ }^{45}$ and provides for education and research functions. ${ }^{46}$ To facilitate detailed implementation of the WADA Code, WADA has established a set of international standards covering the list of prohibited doping substances and methods, ${ }^{47}$ testing, ${ }^{48}$ laboratories, ${ }^{49}$ therapeutic use exemptions ${ }^{50}$ and the protection of privacy and personal information. ${ }^{51}$

Collectively, the antidoping rules adopted by sports governing bodies constitute a system of worldwide private rulemaking, which may be without peer in reach and social significance. As such, it constitutes an important but largely overlooked element in the emerging concept of "global law." system is complemented by significant public law elements, including the UNESCO Convention and other international documents, ${ }^{53}$ domestic antidoping legislation, ${ }^{54}$ and specialized national antidoping agencies. ${ }^{55}$ It is significant that the WADA Code, a private

44. Id. art. 13.

45. Id. arts. 20-22.

46. Id. arts. 18-19.

47. 2010 Prohibited List, WORLD ANTI-DOPING AGENCY, http://www.wada-ama.org/ Documents/World_Anti-Doping_Program/WADP-Prohibited-list/WADA_Prohibited_List_2010_EN. pdf (last visited Nov. 6, 2010).

48. International Standard for Testing 2009, WORLD ANTI-DOPING AGENCY, http:// www.wada-ama.org/Documents/World_Anti-Doping_Program/WADP-IS-Testing/WADA_Int. Standard_Testing_2009_EN.pdf (last visited Nov. 6, 2010).

49. International Standard for Laboratories 2009, WORLD ANTI-DOPING AGENCY (2008), http;/www.wada-ama.org/Documents/World_Anti-Doping_Program/WADP-IS-Laboratories/ WADA_Int.Standard_Laboratories_2009_EN.pdf (last visited Nov. 6, 2010).

50. International Standard for Therapeutic Use Exemptions 2010, WORLD ANTIDOPING AGENCY, http://www.wada-ama.org/Documents/World_Anti-Doping_Program/WADPIS-TUE/WADA_ISTUE_2010_EN.pdf (last visited Nov. 6, 2010).

51. International Standard for the Protection of Privacy and Personal Information 2009, WORLD ANTI-DOPING AGENCY, http://www.wada-ama.org/Documents/World_AntiDoping_Program/WADP-IS-PPPI/WADA_IS_PPPI_2009_EN.pdf (last visited Nov. 6, 2010).

52. See infra notes $98-101$ and accompanying text.

53. See supra notes 32-33 and accompanying text.

54. See, for example, China's 2004 antidoping regulations enacted pursuant to AntiDoping Regulations, CHINA ANTT-DOPING AGENCY, http://www.chinada.cn/en/contents/64/ 2046.html (last visited Nov. 12, 2010). See also DuBIN, supra note 27.

55. Some national antidoping agencies such as Drug FrEe SpORT New Zealand, http://www.drugfreesport.org.nz (last visited Nov. 6, 2010), and the SOUTH AFRICAN INST. FOR DRUG-FrEE SPORT, http://www.drugfreesport.org.za (last visited Nov. 12, 2010) are public entities established by legislation (respectively the Sports Anti-Doping Act, 2006 (N.Z.) and South African Institute for Drug-Free Sport Act 14 of 1997). However, not all national antidoping agencies are state bodies; notable examples of private nonprofit bodies are the CANADIAN CENTRE FOR ETHICS IN SPORT, http://www.cces.ca (last visited Nov. 12, 2010) and the UNITED STATES ANTI-DOPING AGENCY, http://www.usada.org (last visited Nov. 12, 2010), although each is officially recognized by their respective governments as the national antidoping agency. 
arrangement, and the extensive system of international and domestic private rules based on the WADA Code have been rapidly granted important legal recognition by the UNESCO Convention and many national governments.

Some have claimed, "Nowhere is the interconnection between sport and law more evident than in relation to doping." measures arguably provide a rich source of interesting (and often legally controversial) issues warranting the close attention of academics who might not necessarily look to sport as a fertile ground for scholarly inquiry.

The success and speed with which global antidoping regulation has been constructed make a valuable case study for scholars studying the development of international laws and legal systems. Two features are particularly noteworthy. First, it establishes an international rule of law applicable to Olympic and international sports competition as well as domestic athletic competition in most countries. The WADA Code, as interpreted and applied by the Court of Arbitration for Sport, establishes an advanced global system of justice, which creates a more or less uniform set of internationally respected and enforceable legal rules. ${ }^{57}$ The popularity and reach of sports across cultural, economic, political, and social divides has the potential to confer on this system of justice a global profile rarely, if at all, shared by other international systems of justice establishing, for example, criminal law, antidiscrimination law, or other human rights legal norms. ${ }^{58}$ As such, it has a significant capacity to foster appreciation of the need for a uniform international rule of law, particularly in parts of the world where international legal norms generally are not recognized, as well as a sense of global connectivity and legal harmony.

Second, scholars may be interested in exploring the reasons for this success, which may provide a paradigm for solving other pressing international legal issues on which progress may be foundering (e.g., global warming) or worldwide solutions are needed (e.g., global banking regulation). A possible distinctive feature of the process for developing an international body of sports antidoping law has been the important leadership role played by the private sector. This is apparent in the ability initially to command support for specific antidoping measures within the ranks of sports worldwide and then to convince

56. HOULIHAN, supra note 17 , at 174.

57. WADA Code, supra note 15, art. 13.

58. See infra notes 160-167 and accompanying text. 
governments to participate in meaningful working partnerships. ${ }^{59}$ Private international interest groups may have an inherently superior ability and the necessary flexibility to react more effectively to worldwide problems compared with national governments, which may lack international vision, be constrained by domestic politics, and/or be subject to adverse domestic political consequences if nationalistic interests are compromised. This is not to preempt other explanations and lessons, but merely to suggest some lines of scholarly inquiry when examining environmental, economic, and cultural issues with an international dimension.

\section{III. “LEX SPORTIVA": LESSONS FOR GLOBAL DISPUTE RESOLUTION AND THE CREATION OF INTERNATIONAL LEGAL NORMS}

\section{A. Adjudication of Olympic and International Sports Disputes: The Need for a Specialized International Tribunal}

There are national Olympic committees (NOCs) in more than 200 countries or territories throughout the world that promote, sponsor, and oversee Olympic and international sports competitions. Each of them must comply with the IOC Charter and bylaws, as well as the laws of their respective countries. In addition, NGBs, which oversee and regulate a particular sport in their respective countries, are required to adhere to the rules of their respective IFs, which oversee and regulate the sport worldwide, as well as applicable national laws. ${ }^{60}$ Thousands of athletes are members of the corresponding NGB for their respective sports, which provides them with various contractual rights and duties.

Each international or national sports governing body, as well as each individual athlete who participates in Olympic or other international sports competitions, has a "home" country on account of incorporation, domicile, or residence therein and is both subject to and protected by its domestic laws. Because their respective home countries and national laws are different, resolution of Olympic and international sports disputes among two or more of these entities (e.g.,

59. The tightly knit pyramid structure of the Olympic Movement, combined with its authority to exclude particular sports from the Olympic Games, have given the IOC the necessary leverage to exert considerable pressure on international sports goveming bodies to adopt the WADA Code. In addition, the IOC is able to condition a country's hosting of the Olympic Games on its government's adoption, compliance, and enforcement of the WADA Code.

60. See generally MITTEN ET AL., supra note 2, at 278-80. 
IOC, IF, NOC, or NGB) and/or individual athletes by national courts is inherently problematic and raises complex jurisdictional and choice of law issues. For example, in Reynolds v. International Amateur Athletic Federation, the United States Court of Appeals for the Sixth Circuit held that an Ohio district court lacked personal jurisdiction over a London-based IF in litigation brought by a U.S. athlete domiciled in Ohio, who challenged a Paris laboratory's finding that a urine sample he provided in Monaco tested positive for a banned performanceenhancing substance and claimed that his suspension from competition violated Ohio state law. ${ }^{61}$

Because the IOC and each IF seek to apply and enforce a set of uniform rules consistently worldwide, the prospect of different national courts reaching inconsistent conclusions on the merits of Olympic and international sports disputes is a significant problem. ${ }^{62} \mathrm{~A}$ strong potential for conflicting judicial views exists because of the divergent approaches of the world's different legal systems (e.g., common law or civil law), possible biases stemming from nationalism and ethnocentrism, and the strength of the principles of judicial independence and rule of law in the relevant jurisdictions, as well as cultural differences concerning the role and importance of sports and different national and transnational models of sport (e.g., European, North American, and Australian). ${ }^{63}$

61. Reynolds v. Int'l Amateur Athletic Fed'n, 23 F.3d 1110 (6th Cir. 1994).

62. In addition, it is questionable whether national courts have the requisite expertise to resolve international sports disputes. Judge Richard Posner, a prominent federal appellate court judge, has observed: "[T]here can be few less suitable bodies than the federal courts for determining the eligibility, or the procedures for determining the eligibility, of athletes to participate in the Olympic Games." Michels v. U.S. Olympic Comm., 741 F.2d 155, 159 (7th Cir. 1984) (Posner, J., concurring).

63. Distinctive U.S. features: separate regulatory authority based on level of competition; "amateur" intercollegiate and interscholastic competition; closed professional leagues; no national sports ministry or direct federal government regulation; Olympic sports privately funded rather than state-sponsored training schools that financially support athletes. European features: central government funding, regulation, and encouragement of sports participation; club sport model rather than tie to educational institutions; open leagues and promotion and relegation; hierarchical vertical pyramid. See generally James A.R. Nafziger, A Comparison of the European and North American Models of Sports Organisation, in EU, SPORT, LAW AND POLICY: REgulation, Re-REGUlation AND REPRESENTATION 35-55 (Simon Gardiner, Richard Parrish \& Robert C.R. Siekmann eds., 2009). Australian features: influenced by large geographic size and a smaller market with widely separated population centers; until relatively recently, entire semi-professional leagues located in each major center; national professional leagues now established; closed professional leagues; private ownership of professional teams either nonexistent or new; club sports model rather than university-based sports; strong government sports development policy; many professional leagues include a New Zealand based team. See Bob StEWART ET AL., AUSTRALIAN SPORT: BETTER BY DESIGN? (2004). 
If national courts adjudicate these disputes, there is an inherent tension between internationalism (i.e., the need for international sports to operate under a consistent, worldwide legal framework), and nationalism (i.e., the desire of each nation to preserve its sovereignty and ensure that its athlete citizens are protected by its laws). Olympic and international sports competition requires uniform and generally accepted rules governing on-field competition that are interpreted, applied, and enforced by independent and impartial referees, umpires, or judges whose decisions are final. Similarly, the resolution of disputes arising out of Olympic and international sports competition also requires an off-field legal system pursuant to which an independent international tribunal or court with specialized sports law expertise renders final and binding decisions having global recognition and effect. ${ }^{64}$

\section{B. Court of Arbitration for Sport (CAS)}

In 1981, Juan Antonio Samaranch, who was the then-current IOC president, envisioned a "supreme court for world sport."65 On April 6, 1983, the IOC established the CAS, a private international arbitral body based in Lausanne, Switzerland, to provide a forum for resolving sports-related disputes. ${ }^{66}$ The CAS is the product of a 1982 working group chaired by Judge Kéba Mbaye, who was an IOC member and judge on the International Court of Justice. ${ }^{67}$ Despite the first word of its name, the CAS is not an international court of law. Rather, it is an arbitration tribunal whose jurisdiction and authority are based on agreement of the parties.

64. See generally Matthew J. Mitten, Judicial Review of Olympic and International Sports Arbitration Awards: Trends and Observations, 10 PEPP. DISP. RESOL. L.J. 51 (2009).

65. Daniel H. Yi, Turning Medals into Metal: Evaluating the Court of Arbitration of Sport as an International Tribunal, 6 ASPER REV. INT'L BUS. \& TRADE L. 289, 290 n.7 (2006) (quoting Ian Blackshaw, Sports Court Getting Right Results, GuARDIAN, June 3, 2004, http:// www.guardian.co.uk/sport/2004/jun/03/ianblack (last visited Nov. 6, 2010)).

66. The CAS is recognized under the European Convention on the Recognition of the Legal Personality of International Non-Governmental Organizations. Ian S. Blackshaw, Introductory Remarks to THE COURT OF ARBITRATION FOR SPORT 1984-2004, at 4 (lan S. Blackshaw et al. eds., 2006) ("CAS rulings are legally effective and can be enforced internationally.").

67. Matthieu Reeb, The Role and Functions of the Court of Arbitration for Sport (CAS), in THE COURT OF ARBITRATION FOR SPORT 1984-2004, at 31, 32 (Ian S. Blackshaw et al. eds., 2006). 
The Code of Sports-Related Arbitration (Code), ${ }^{68}$ which is drafted by the International Council of Arbitration for Sport (ICAS), a group of twenty high-level jurists, governs the organization, operations, and procedures of the CAS. ${ }^{69}$ The Code empowers the CAS to resolve sports-related disputes in the first instance (i.e., ordinary arbitration, which usually involves commercial matters) and those arising out of the appeal of a decision of a sports governing body such as the IOC or an IF (i.e., appeals arbitration). ${ }^{70}$ The CAS operates an ad hoc Division at the site of each Olympic Games as well as other major international sports events to resolve disputes in connection with the event in an expedited manner. ${ }^{71}$ It also is authorized to issue nonbinding advisory opinions on sports-related matters.

The ICAS appoints the CAS's member-arbitrators for four-year renewable terms and is obligated to "wherever possible, ensure fair representation of the continents and of the different juridical cultures." " In appointing CAS arbitrators, the Code states that "the ICAS shall respect, in principle, the following distribution:" one-fifth from among persons nominated by the IOC; one-fifth from among persons nominated by the IFs; one-fifth from among persons nominated by the NOCs; one-fifth from among persons independent of those sports governing bodies; and one-fifth "with a view to safeguarding the interests of the athletes." training, recognized competence in sports law and/or international arbitration, and have good command of at least one CAS working language (i.e., English or French). ${ }^{74}$ In addition, CAS arbitrators must be objective and independent in their decisions and adhere to a duty of confidentiality. Presently, there are approximately 270 CAS arbitrators who generally sit in three-person panels to hear and adjudicate cases. ${ }^{75}$

68. Code of Sports-Related Arbitration, COURT OF ARBITRATION FOR SPORT, http:// www.tas-cas.org/d2wfiles/document/3923/5048/0/Code\%202010\%20(en).pdf (last visited Nov. 6, 2010) [hereinafter Arbitration Code].

69. ICAS currently has two U.S. members, Michael B. Lenard and Judge Juan R. Torruella, and one Australian member, John D. Coates, who is the ICAS Vice-President.

70. Arbitration Code, supra note $68, \S 20$.

71. These include the FIFA World Cup, Commonwealth Games, and Union of European Football Associations (UEFA) European Football Championships.

72. Arbitration Code, supra note $68, \S 16$.

73. Id. $\S 14$.

74. Id. $\S 14$, r. 29.

75. List of CAS Arbitrators Per Nationality, COURT OF ARBITRATION FOR SPORT, http:/www.tas-cas.org/d2wfiles/document/452/5048/0/Liste\%20nationalité\%202009.pdf (last visited Nov. 10, 2010). 
Regardless of its geographical location, the "seat" of all CAS arbitration proceedings is Lausanne, Switzerland. ${ }^{76}$ This ensures uniform procedural rules, ${ }^{77}$ provides a stable legal framework, ${ }^{78}$ and facilitates efficient dispute resolution in locations convenient for the parties. The CAS panel issues a written award (majority vote governs) giving the reasons for the decision, which is final and binding on the parties. CAS appeals arbitration (unless the parties agree otherwise) and ad hoc Division awards are publicly disclosed.

Unlike common law judicial precedent, "[i]n CAS jurisprudence there is no principle of binding precedent, or stare decisis." "79 Ironically, although the CAS is an arbitral tribunal and the majority of its arbitrators have a civil law background, the rapidly developing body of CAS awards collectively is forming a body of international sports law, which has been described as lex sportiva. ${ }^{80}$ For consistency, although it is not bound to do so, "a CAS Panel will obviously try, if the evidence permits, to come to the same conclusion on matters of law as a previous CAS Panel." ${ }^{\prime 81}$ This is similar to the judicial process utilized

76. Arbitration Code, supra note 68, r. 28.

77. See Gabrielle Kaufmann-Kohler, Identifying and Applying the Law Governing the Arbitration Procedure-The Role of the Law of the Place of Arbitration, in IMPROVING THE EFFICIENCY OF ARBITRATION AGREEMENTS AND AWARDS: 40 YEARS OF APPLICATION OF THE NEW YORK CONVENTION 336, 348 (Albert Jan van den Berg ed., 1999) (noting that the objective of choosing Lausanne as the seat of CAS arbitrations is to provide the advantage of a "uniform procedural regime").

78. The Swiss Federal Code on Private International Law, reprinted in COURT OF ARBITRATION FOR SPORT, CODE OF SPORTS-RELATED ARBITRATION AND MEDIATION RULES app. 3 , at 162 (2004) [hereinafter PIL], requires an arbitration tribunal to resolve a dispute pursuant to the rules of law chosen by the parties, or absent any choice, according to the law with the closest connection to the dispute. Article 187. The choice of law rules in the CAS Code are consistent with the Swiss PIL. See infra notes 128-130 and accompanying text.

79. Arbitration CAS 2004/A/628, Int'] Ass'n of Athletics Fed'n (IAAF) v. USA Track \& Field, award of June $28,2004, \S 19$.

80. Michafl J. Beloff, Tim KerR \& Marie Demetriou, Sports LaW 7-12 (1999); JAMES A.R. NAFZIGER, INTERNATIONAL SPORTS LAW 48-54 (2d ed. 2004). But see Allan Erbsen, The Substance and Illusion of Lex Sportiva, in THE COURT OF ARBITRATION FOR SPORT 1984-2004, at 441 (Ian S. Blackshaw, Robert C.R. Siekmann \& Janwillem Soek eds., 2006) (concluding that it is inaccurate to describe collective body of CAS awards as lex sportiva). For additional discussion on lex sportiva, see Ken Foster, Is There a Global Sports Law? 2 ENT. L. 1 (2003); Ken Foster, Lex Sportiva and Lex Ludica: The Court of Arbitration for Sport's Jurisprudence, 3 ENT. \& SPORTS L.J. (2006), available at http://www2.warwick. ac.uk/fac/soc/law/elj/eslj/issues/volume3/number2.

81. Arbitration CAS 2004/A/628, Int'l Ass'n of Athletics Fed'n (IAFF) v. USA Track \& Field (USATF), award of June 28, 2004, § 19. See also Arbitration CAS 2008/A/1545, Anderson et al. v. Int'l Olympic Comm. (IOC), award of July 16, 2010, \& 118 ("[A]lthough a CAS panel in principle might end up deciding differently from a previous panel, it must accord to previous CAS awards a substantial precedential value and it is up to the party advocating a jurisprudential change to submit persuasive arguments and evidence to that effect."). 
by common law appellate judges. The CAS Code provides that a CAS award is final and binding on the parties ${ }^{82}$ but is subject to limited judicial review by the Swiss Federal Tribunal (SFT), which has ruled that the CAS is sufficiently independent and impartial for its awards to have the same force and effect as judgments rendered by sovereign courts. $^{83}$

\section{CAS: A Fertile Ground for Academic Study}

The twenty-five-year history of the CAS demonstrates how civil and common law legal systems can function effectively together within an international tribunal to resolve a wide variety of complex, timesensitive disputes between parties of different nationalities. CAS arbitration awards are globally respected adjudications, which generally are validated and enforced by national courts. The CAS offers guidance regarding the effective structure and operation of international and transnational dispute resolution bodies, which are increasing in number with globalization. ${ }^{84}$

One commentator has observed that "the CAS represents one of the world's more successful attempts at bringing order to transnational issues" $"$ and is a "valuable example of how an international tribunal can succeed." officials have created a working, functioning international tribunal that

82. Arbitration Code, supra note 68, r. 59. See infra notes 127-133 and accompanying text for a discussion of the nature and scope of the SFT's judicial review of CAS awards.

83. A. and B. v Int'l Olympic Comm. (IOC) and Int'l Ski Fed'n (FIS) (Lazutina), 4P.267-270/2002 (1st Civ. Ct., May 27, 2003) (translation), in DiGEST OF CAS AWARDS III 2001-2003, at 674 (Matthieu Reeb ed., 1998); G. v Fédération Equestre Internationale, (1st Civ. Ct., Mar. 15, 1993) (translation), in DigeST OF CAS AWARDS 1986-1998 561 (Matthieu Reeb ed., 1998). Notwithstanding the SFT's ruling, some commentators question whether the CAS is sufficiently independent from the IOC and some members of the Olympic Movement. See, e.g., ANTONIO RigozZI, L'ARBITRAGE INTERNATIONAL EN MATIËRE DE SPORT (2005); Andrea Pinna, The Trials and Tribulations of the Court of Arbitration for Sport: Contribution to the Study of the Arbitration of Disputes Concerning Disciplinary Sanctions, 1-2 INT'L SPORTS L.J. 8, 13-14 (2005); Michael Straubel, Enhancing the Performance of the Doping Court: How the Court of Arbitration for Sport Can Do Its Job Better, 36 LoY. U. CHI. L.J. 1203, 1231-32 (2005).

84. See The International Judiciary in Context, ProJeCT ON INT'L CourTs AND TRIBUNALS, http://www.pict-pcti.org/publications/synoptic_chart/synop_c4.pdf (last visited Nov. 6, 2010) (listing several permanent arbitral tribunals).

85. Yi, supra note 65, at 290; see also Lisa B. Bingham, Control over Dispute-System Design and Mandatory Commercial Arbitration, 67 LAW \& CONTEMP. PROBS. 221, 245 (2004) (observing that the CAS "has earned a reputation for independence and fairness, although it, too, is a mandatory arbitration program" and "is viewed as establishing a consistent body of arbitral authority, a kind of lex sportiva, because of its combination of expertise and transparency").

86. Yi, supra note 65 , at 291 . 
can serve as an example for future efforts at transnational dispute resolution." ${ }^{987}$ The CAS has been successful because it is a superior dispute resolution forum than available alternatives, and its decisions are generally accepted and will be enforced by national courts if necessary. ${ }^{88}$ Alternative dispute resolution scholars would find it interesting to compare the structure and operation of the CAS to other international arbitral bodies such as the International Court of Arbitration (which resolves commercial disputes) and the ICANN Arbitration System (which resolves disputes regarding the ownership of internet domain names) and to evaluate their relative effectiveness in resolving disputes fairly, efficiently, and consistently.

For legal theorists, the evolving body of lex sportiva established by CAS awards is an interesting and important example of global legal pluralism without states, arising out of the resolution of Olympic and international sports disputes between private parties. ${ }^{89}$ It is an emerging body of international law with some similarities to lex mercatoria, a much older and more well-established body of international commercial law that has developed in the essentially private domain of commercial activity based on custom and arbitration awards. ${ }^{90}$ However, the lex sportiva being developed by the CAS often is not recognized as an illustrative example of legal pluralism that

87. Id.

88. See infra notes $135-136$ and accompanying text.

89.

[The] globalization of law creates a multitude of decentred law-making processes in various sectors of civil society, independently of nation-states.... They claim worldwide validity independently of the law of nation-states and in relative distance to the rules of international public law. They have come into existence not by formal acts of nation-states but by strange paradoxical acts of self-validation.

GUNTHER TEUBNER, Global LAW WITHOUT A STATE, at xiii (1997).

90. Arbitration CAS 98/200, AEK Athens v. Union of European Football Ass'n (UEFA), award of Aug. 20, 1999, § 156:

Sports law has developed and consolidated along the years, particularly through the arbitral settlement of disputes, a set of unwritten legal principles-a sort of lex mercatoria for sports or, so to speak, a lex ludica-to which national and international sports federations must conform, regardless of the presence of such principles within their own statutes and regulations or within any applicable national law, provided that they do not conflict with any national $<<$ public policy $>>(<<$ ordre public $>>)$ provision applicable to a given case.

But see Nafziger, supra note 80 , at $48-49$ (observing that "the association of the two terms may be somewhat strained" because "the status and general scope of the emerging lex sportiva are ... much less substantial than the lex mercatoria within their respective spheres of application"). 
appears to work well, even by those who staunchly advocate private adjudication of disputes. ${ }^{91}$

Now that CAS appeals arbitration procedure and ad hoc Division awards are becoming more readily identifiable and accessible to the public, ${ }^{92}$ there are several broad issues worthy of in-depth academic study regarding the development of this body of international sports law by a diverse group of international arbitrators with civil law or common law backgrounds. For example, to gain a comparative perspective, alternative dispute resolution and international law scholars may want to study the following issues:

1. How do CAS arbitration panels decide cases, and does the panel's role vary according to the type of dispute? $?^{93}$ Do CAS panels simply construe the parties' agreement and applicable rules, exercise "equity jurisdiction" as deemed appropriate, and/or perform other functions similar to a common law, civil law, or hybrid legal system? Is there discernable empirical evidence of any factors that significantly influence which party prevails in particular types of disputes?

2. Considering the plenary power of monolithic Olympic and international sports governing bodies, which require athletes to submit to final and binding CAS arbitration as a condition of participation, ${ }^{94}$ what should be the appropriate role of the CAS?

91. See, e.g., Bryan Caplan \& Edward P. Stringham, Privatizing the Adjudication of Disputes, 9 THEORETICAL INQUIRIES IN L. 503, 528 (2008) (asserting that "[p]ublic courts should, as a matter of policy, respect contracts that specify final and binding arbitration," but failing to cite the CAS and its arbitration awards as an example, which would have strengthened their argument).

92. Recently, the CAS Secretary General began posting the full text of current CAS awards on the CAS Web site and is developing a searchable archive of past awards. Pursuant to an agreement with the United States Olympic Committee (USOC), the National Sports Law Institute (NSLI) of Marquette University Law School is developing an electronic summary and index of issues resolved by CAS awards that will be posted on both the USOC and NSLI Web sites.

93. See, e.g., Erbsen, supra note 80, at 452 (finding a "strong textualist theme in CAS [doping] opinions").

94. In $X$. (Cañas) v ATP Tour, 4P.172/2006 (2007) (Switz.), ATF 133 III 235, translated in 1 Swiss INT'L ARB. L. REP. 65, 84-85, the SFT recently observed:

Sports competition is characterized by a highly hierarchical structure, as much on the international as on the national level. Vertically integrated, the relationships between athletes and organisations in charge of the various sports disciplines are distinct from the horizontal relationship represented by a contractual relationship between two parties .... This structural difference between the two types of relationships is not without influence on the volitional process driving the formation of every agreement.... [E]xperience has shown that, by and large, athletes will often not have the bargaining power required and would therefore have 
Should CAS arbitrators have a broad scope of equitable power and function more like a court by acting as an external regulatory constraint and ensuring that the legal rights of particular parties (e.g., Olympic and international sport athletes) are protected adequately? ${ }^{9}$

3. Is CAS jurisprudence functioning as a de facto body of common law legal precedent and, if so, what are its effects? ${ }^{96}$ For example, is it reducing the volume of CAS arbitration proceedings in particular types of disputes as it establishes a body of lex sportiva?

4. Should the CAS Code be modified (and if so, how?) to improve the fairness and effectiveness of CAS arbitration as a method of international sports dispute resolution with global implications? ${ }^{97}$

to submit to the federation's requirements, whether they like it or not. Accordingly, any athlete wishing to participate in organised competition under the control of a sports federation whose rules provide for recourse to arbitration will not have any choice but to accept the arbitral clause, in particular by subscribing to the articles of the sports federation in question in which the arbitration clause was inserted ...."

It ruled that mandatory arbitration provisions are enforceable because the CAS provides a swift, independent, and impartial means of resolving international sports disputes by a specialized tribunal. However, as a "counterbalance," an athlete must have a right to have an adverse CAS award judicially reviewed by the SFT to remedy "breaches of fundamental principles and essential procedural guarantees that which may be committed by the arbitrators called upon to decide in his case." Id. at 86.

95. A CAS panel will not rewrite an international sports governing body's rules or second-guess its decisions or policies. Arbitration CAS 2006/A/1165, Ohuruogu v. U.K. Athletics Ltd., award of Apr. 3, 2007, at 11-12. On the other hand, one CAS panel has recognized the need for "general principles of law" to govern international sports federations in addition to their own rules or applicable national law. For example, procedural fairness should be required, and "arbitrary or unreasonable rules and measures" should be prohibited. Arbitration CAS 98/200, AEK Athens v. Union of European Football Ass'n (UEFA), award of Aug. 20, 1999, para. 156.

96. One scholar has suggested:

Consideration should also be given to an organizational structure whereby CAS can address the development of law in arbitral sporting decisions. CAS decision [sic] are increasingly cited by parties and arbitral panels as authority for rules upon which to decide cases, yet the persuasive effect of these citations to arbitral cases is unclear. For CAS to be a true "Supreme Court for Sport," it should institute a formal appellate body akin to a U.S. Supreme Court with discretionary review, to rule on conflicting interpretations of lex sportiva rendered by CAS panels.

Maureen A. Weston, Simply a Dress Rehearsal? U.S. Olympic Sports Arbitration and De Novo Review at the Court of Arbitration for Sport, 38 GA. J. INT'L \& COMP. L. 97, 128 (2009).

97. For example, considering that Olympic sports organizations currently provide substantial funding for the CAS and appoint sixty percent of the members of the ICAS, which has the exclusive authority to appoint CAS arbitrators (many of whom have ties to Olympic sports governing bodies), is it appropriate to have a closed list of CAS arbitrators? 
Examination of these issues by academics other than sports law scholars may provide not only valuable research specific to the CAS, but it also may contribute some important insights regarding the development of alternative dispute resolution systems and/or international legal norms outside the context of sports.

\section{INTERNATIONAL SPORTS LAW, A FORM OF GLOBAL LEGAL PluRALISM, AND PROSPECTS FOR DISPlaCING NATIONAL $\mathrm{LAW}^{98}$}

In Part III.A, we identified an inherent tension between internationalism and nationalism in the adjudication of sports disputes arising out of international athletic competition. The establishment and development of the CAS has provided an effective mechanism for resolving Olympic and international sports disputes in an expert and internationally coherent manner, thereby largely avoiding the problems of inconsistent rulings by national courts unfamiliar with international sports association governance and rules. In this Part, we will explore another aspect of the tension between internationalism and nationalism in sports, namely an actual or potential clash between a developing body of international sports law and national law. ${ }^{99}$ This conflict arises primarily in two situations: (1) when international sports governing body agreements and rules are directly challenged in domestic courts

In addition, scholarly analysis of the current CAS arbitrator conflict of interest rules and SFT rulings regarding the grounds for challenging a CAS arbitrator's independence is needed.

98. There are, however, some significant areas of law in which displacement is very unlikely to occur. For example, criminal laws generally apply to sports-related conduct within a country. The Italian government refused to honor the Turin Olympic Games Organizing Committee's promise that Italy's criminal sports doping laws would not be enforced during the 2006 Turin Olympics against foreign Olympic athletes. Rosie DiManno, A Gold in the Scandal Event; This Year It Goes to the Austrians, TORONTO STAR, Feb. 22, 2006, at A6; Phil Sheridan, Italy's Drug Laws Put IOC to the Test, PHILA. INQUIRER, Feb. 9 , 2006 , at H2. Visiting foreign athletes have been prosecuted for violating domestic criminal laws despite the assertion of a private sports league that player discipline for on-ice violence should be exclusively an internal governance matter. For example, in 2000, the Boston Bruins' Marty McSorley was convicted of assaulting Donald Brashear, a Vancouver Canucks' player, with a weapon (a hockey stick) during an NHL game. MrTTEN, supra note 2, at 92631 (discussing R v. McSorley, 2000 BCPC 116 (Can. B.C. 2000)). National tax laws also apply to income earned by foreign athletes within a county's borders, although it is important to avoid double taxation by multiple countries. See THE INTERNATIONAL GUIDE TO THE TAXATION OF SPORTSMEN AND SPORTSWOMEn (Rijkele Betten ed., 2004); Rijkele Betten, The Avoidance of the International Double Taxation of Sportspersons, 1-2 INT'L SPORTS L.J. 78 (2004).

99. Some other examples are cited in AleXANDRE Miguel MESTRE, THE LAW OF THE OLYMPIC GAMES 16-18 (2009). 
as contrary to national law and (2) when CAS awards are challenged as inconsistent with national law in a judicial forum.

It is inevitable that sports governing body rules based on private international agreements and/or CAS awards at times will create tensions with national laws. Because sports are a microcosm of society, ${ }^{100}$ an examination of how these conflicts are being resolved and the corresponding effects is fertile ground for academic discourse. Sports are a crucible for consideration of important global legal issues and presents an opportunity to examine the intersection between global alternative dispute resolution, international law, and national sovereignty. ${ }^{101}$

In their introduction to a recent American Journal of Comparative Law symposium issue on Beyond the State: Rethinking Private Law, the authors observe that "it is precisely because globalization moves us 'beyond the state' that we are, more than ever, forced to rethink private law and its relation to the state., 102 One of the issue's fifteen articles recognizes-in a cursory and rather oblique manner-that international sports federation ethical codes and disciplinary sanctions for violations are a form of global private law. ${ }^{103}$ Another article briefly notes that rules regulating economic transactions among sports

100. See generally Matthew J. Mitten, Foreword, 38 S. TEX. L. REv. 999 (1997).

101. Almost twenty years ago, Professor James Nafziger, a leading international law and international sports law scholar, observed:

The much-neglected field of international sports law is changing significantly.... The evolving legal framework has important implications for participants and spectators in both sports and the international legal process. Among students and practitioners of international law, the role of nongovernmental sports organizations in gaining governmental and intergovernmental support, in shaping a still immature body of law, in acquiring a measure of legal personality, and in responding to new issues is of general professional interest. Athletic competition is a fundamental human activity whose history has been replete with international problems. Understanding the peculiar blending of governmental, intergovernmental and nongovernmental authority over political and other consequences of sports activity is therefore significant.

James A.R. Nafziger, International Sports Law: A Replay of Characteristics and Trends, 86 AM. J. INT'L L. 489, 489 (1992) (footnote omitted); see also James A.R. Nafziger, International Sports Law as a Process for Resolving Disputes, 45 INT'L \& COMP. L.Q. 130, 149 (1996) ("Normative trends thus confirm a growing commitment of national legal systems to the special processes of international sports law. The [CAS], in particular, is assuming a central position for avoiding, managing and resolving international disputes. What remains is for the legal profession throughout the world to take international sports law seriously.").

102. Nils Jansen \& Ralf Michaels, Beyond the State? Rethinking Private Law: Introduction to the Issue, 56 AM. J. CoMP. L. 527, 527 (2008).

103. Christiane C. Wendehorst, The State as a Foundation of Private Law Reasoning, 56 AM. J. COMP. L. 567, 593-95 (2008). 
federation members, such as player transfers, also constitute global private law. ${ }^{104}$ However, although Olympic and international sports competition gives rise to a paradigm example of global legal pluralism, ${ }^{105}$ neither article recognizes the two situations in which a developing body of international sports law arising primarily out of the resolution of disputes between private parties interacts with national law, much less considers or analyzes this phenomenon from a scholarly perspective. ${ }^{106}$

\section{A. Evolving Judicial Treatment of International Sports Agreements and Rules: Traditional vs. Deferential Approach}

As the scope and detail of Olympic and international sports rules continue to expand, they may conflict with national laws, thereby motivating athletes and others to seek the aid of a national court to overturn the adverse effects of those rules, at least within their

104. Jürgen Basedow, The State's Private Law and the Economy Commercial Law as an Amalgam of Public and Private Rule-Making, 56 AM. J. COMP. L. 703, 709-1 1 (2008).

105. Legal pluralism is based on "the premise that people belong to (or feel affiliated with) multiple groups and understand themselves to be bound by the norms of these multiple groups." Paul Schiff Berman, Global Legal Pluralism, 80 S. CAL. L. REv. 1155,1169 (2007). "[M]any community affiliations ... may at various times exert tremendous power over our actions even though they are not part of an 'official' state-based system." Id. at 1170 . Thus, "situations [arise] in which two or more state and non-state normative systems occupy the same social field and must negotiate the resulting hybrid legal space." Id. Conflicts arising out of overlapping legal rules created by Olympic and international sports private agreements and national laws must be resolved either by "reimposing the primacy of territorially-based (and often nation-state-based) authority or by seeking universal harmonization." Id. at 1162 .

106. The tide, however, is changing. In his concluding remarks during the 60th Congress of the International Association of Legal Science, which was hosted by the Istanbul University Law Faculty Centre for Comparative Law, in Istanbul, Turkey, on May 13-14, 2010, Mauro Bussani, Professor of Comparative Law at the University of Trieste, Italy, observed that comparative sports law is a "very attractive scientific discipline." He stated:

[C]onceiving sports law just as a legal specialization, in which national and international legal doctrines are subject to special deviations, exceptions, exclusions, would be inconsistent with reality. As my learned colleagues showed us during these two days, sports law can indeed be viewed as a legal system in itself.

$\cdots$

As any legal system, sports law has its own institutions, procedures, and rules. As most legal systems, it is made up of different layers, which present themselves as stratified one upon the other. Some of these layers are regionally fragmented, while others have been internationally harmonized by homogenous practices. Legal solutions often circulate from one region to the other ones, and frequently this circulation gives rise to legal transplants and legal borrowing.

Mauro Bussani, Professor of Comparative Law at the University of Trieste, Italy, Remarks at 60th Congress of the Int'l Ass'n of Legal Science (May 13-14, 2010) (transcript on file with authors). 
respective home countries. Unless doing so would contravene valid and applicable choice of law provisions, a domestic court generally will apply its substantive national law in resolving disputes within its jurisdiction. Therefore, Olympic and international sports agreements and rules must comply with national law, and some domestic courts have ruled accordingly. On the other hand, other courts have adopted a deferential approach by refusing to apply national law to the challenged rules or agreements.

The following 1988 case illustrates the traditional judicial approach. In Barnard $v$ Australian Soccer Federation, the Federal Court of Australia ruled that the Australian Soccer Federation (ASF) violated Australian competition law by banning the plaintiff, who played both semiprofessional indoor and outdoor soccer, from competing in outdoor soccer competitions. ${ }^{107}$ At the time, the Federation of International Football Associations (FIFA), the IF for soccer, and the Federação Internacional de Salão (FIFUSA) were rivals for governing authority over the emerging game of indoor soccer. FIFA sought to extend its control to encompass indoor as well as outdoor soccer by directing its national affiliated bodies, including the ASF, to impose bans on players who played in FIFUSA-sponsored indoor soccer competitions. In turn, the ASF directed its regional affiliate, the Queensland Soccer Federation, to ban the plaintiff from playing in its outdoor competitions. Recognizing the primacy of Australian national law, the court rejected the ASF's defense that it was contractually obligated to follow FIFA's rules and may be disciplined by FIFA for failing to ban the plaintiff.

An analogous example of the traditional approach is the European Court of Justice (ECJ)'s 1995 ruling applying European transnational laws in Union Royale Belge des Sociétiés de Football Association ASBL v Bosman, perhaps the world's most famous sports law case. ${ }^{108}$ It involved a successful challenge to the core labor market

107. Barnard v Australian Soccer Fed'n (1988) 81 ALR 51.

108. 1995 E.C.R. I-4921 (E.C.J.). The case and its consequences have generated a voluminous literature in books and articles. See, e.g., ROGER BLANPAIN \& RITA INSTON, THE Bosman Case: The END of THE Transfer System? (1996); David MCARdLe, From Boot MONEY to BOSMAN: FoOtBall, SOCIETY AND THE LAW (2000); SteFaAN VAN DEN BOGaERT, Practical Regulation OF THE MOBILITY OF SPORTSMEN IN THE EU POST BOSMAN (2005); Braham Dabscheck, The Globe at Their Feet: FIFA's New Employment Rules-I, SPORT IN Soc'Y, Spring 2004, at 1, 69; Braham Dabscheck, The Globe at Their Feet: FIFA's New Employment Rules-II, SPORT IN SOC'Y, Jan. 2006, at 1, 1; P.E. Morris, S. Morrow \& P.M. Spink, EC Law and Professional Football: Bosman and Its Implications, 59 MoD. L. REV. 893 (1996); Jens Pelle Van den Brink, E.C. Competition Law and the Regulation of Football: 
rules of soccer, the world's most widely played and followed sport. The plaintiff was an out-of-contract Belgian professional player who was offered a contract to play for a French soccer club. The rules of the defendant Belgian soccer governing body incorporated European Union of Football Associations (UEFA) regulations establishing a transfer fee system and limiting the number of nonnationals who could play for domestic professional clubs. Despite plaintiff's uncontracted status, he needed his former club's approval to play for a new club, which was conditioned upon the latter's payment of a prescribed player transfer fee. The player transfer fee requirement was part of an elaborate international system (of which FIFA and UEFA were the main proponents) governing the movement of soccer players between clubs-a system which an English court some years earlier had described as "a united monolithic front all over the world."109 The ECJ held that these rules contravened article 48 of the then-European Community Treaty (now article 45 of the Treaty on European Union (EU Treaty)), which guarantees European workers freedom of movement between member countries and prohibits discrimination on grounds of nationality. ${ }^{110}$ Bosman generated a "welter of publicity,"111 but it was an unsurprising result to informed observers ${ }^{112}$ because the court ruled that international sports rules and agreements are subject to applicable transnational laws; here, a regional international treaty is given domestic application. ${ }^{113}$

Part I, 21 EuR. Competition L. Rev. 359 (2000); Jens Pelle Van den Brink, E.C. Competition Law and the Regulation of Football: Part II, 21 EuR. COMPETITION L. REV. 420 (2000).

109. Eastham v. Newcastle United Football Club Ltd., [1964] Ch. 413 at 438 (Eng.).

110. The ECJ considered it unnecessary to adjudicate plaintiff's claim that the rules contravened articles 85 and 86 (now articles 101 and 102) relating to freedom of economic competition.

111. Morris, Morrow \& Spink, supra note 108, at 902.

112. Courts in other countries had long recognized the contrariness of such transfer systems to laws protecting freedom of economic competition and employment. See, e.g., Mackey v. NFL, 543 F.2d 606 (8th Cir. 1976); Buckley v Tutty (1971) 125 CLR 353 (Austl.); Blackler v N.Z. Rugby Football League, Inc. [1968] NZLR 547. In Europe, serious doubt existed as well. See, e.g., Eastham v. Newcastle United Football Club Ltd., [1964] Ch. 413 (Eng.); Janssen Van Raay, Report of the Committee on Legal Affairs and Citizens'Rights on the Freedom of Movement of Professional Footballers in the Community (European Parliament, Session Documents Series A, Mar. 1, 1989).

113. Bosman demonstrates that court rulings which apply national laws to international sports rules and agreements can prove to be problematic because they do not accommodate the special circumstances and needs of international sports. FIFA responded to the ruling by amending its transfer regulations, which caused some Belgian trade unions to file a complaint with the European Commission alleging contravention of competition law (articles 85 and 86 of the EC Treaty-now articles 101 and 102 of the EU Treaty). Following protracted negotiation and political lobbying, during which FIFA and UEFA were able to convince the Commission of the special economics and social status of soccer, an agreement 
In contrast to the foregoing traditional view is the deferential approach of some courts, which demonstrates a judicial reluctance to apply national laws to Olympic and international sports rules and agreements. For example, some national courts have refused to apply national laws protecting human rights to international sports competitions held within their respective country's borders.

United States courts generally have rejected claimed violations of federal or state law in connection with Olympic Games hosted by American cities. For example, in Martin v. International Olympic Committee, the United States Court of Appeals for the Ninth Circuit affirmed the denial of a preliminary injunction to require the organizers of the 1984 Los Angeles Summer Olympic Games to include 5,000- and 10,000-meter track events for women, which already existed for men. ${ }^{114}$ The court rejected plaintiffs' claims that the failure to include these events constituted illegal gender discrimination, even though "the women runners made a strong showing that the early history of the modern Olympic Games was marred by blatant discrimination against women."'15 The majority explained:

[W] find persuasive the argument that a court should be wary of applying a state statute to alter the content of the Olympic Games. The Olympic Games are organized and conducted under the terms of an international agreement-the Olympic Charter. We are extremely hesitant to undertake the application of one state's statute to alter an event that is staged with competitors from the entire world under the terms of that agreement. ${ }^{116}$

was reached on new Regulations for the Status and Transfer of Players to apply worldwide. See Braham Dabscheck, The Globe at Their Feet: FIFA's New Employment Rules-I, SPORT IN SOC'Y, Spring 2004, at 1, 69. The development of the new rules was strongly influenced by European perspectives and it is an issue worthy of scholarly investigation as to whether the socioeconomic and legal perspectives of Asia and the Americas have been sufficiently considered in adopting these worldwide rules.

114. Martin v. Int'l Olympic Comm., 740 F.2d 670 (9th Cir. 1984). American courts also have rejected state discrimination law claims by foreign athletes seeking to march in opening ceremonies in Olympic Games held in the United States under flags of countries not recognized by the IOC. See Ren-Guey v. Lake Placid 1980 Olympic Games, Inc., 424 N.Y.S.2d 535 (N.Y. App. Div. 1980), aff'd, 429 N.Y.S.2d 473 (1980); Spindulys v. L.A. Olympic Org. Comm., 220 Cal. Rptr. 565 (Cal. Ct. App. 1985).

115. Martin, 740 F.2d at 673 .

116. Id. at 677. The dissenting judge argued:

The IOC made concessions to the widespread popularity of women's track and field by adding two distance races this year. The IOC refused, however, to grant women athletes equal status by including all events in which women compete internationally. In so doing, the IOC postpones indefinitely the equality of athletic opportunity that it could easily achieve this year in Los Angeles. When the Olympics move to other countries, some without America's commitment to human 
Consistent with Martin, the British Columbia Court of Appeal rejected a similar gender discrimination claim under Canadian law in connection with the 2010 Vancouver Olympic Games. In Sagen v. Vancouver Organizing Committee for the 2010 Olympic \& Paralympic Games, the court ruled that the IOC's decision not to include women's ski jumping as an event in the Vancouver Games (while including men's ski jumping events) did not violate the Canadian Charter of Rights and Freedoms (Charter). ${ }^{117}$ The court held that the Charter, which regulates only government conduct, did not apply to the IOC's selection of events for the 2010 Olympics because it is considered private party conduct. Although the Canadian government, province of British Columbia, and cities of Vancouver and Whistler were parties to an agreement with the IOC to host the 2010 Olympics, none of these government entities or the Vancouver Organizing Committee for the 2010 Olympic and Paralympic Games (VANOC), a federally chartered nonprofit corporation, had the authority to determine which events are part of the Vancouver Olympics. Rather, "The Host City Contract stipulates that it is the IOC that sets the Programme,", and VANOC is subject to the "supreme authority of the IOC." not to hold a women's ski jumping event at the 2010 Games is a decision that has not been endorsed by VANOC, or by any Canadian government body." 20

It is important for comparative and international law scholars to be aware of and analyze the underlying jurisprudential issues raised by Barnard and Bosman, ${ }^{121}$ which reflect, on the one hand, the traditional judicial view recognizing that private international sports federation agreements and rules are subject to national and transnational public

rights, the opportunity to tip the scales of justice in favor of equality may slip away. Meanwhile, the Olympic flame - which should be a symbol of harmony, equality, and justice - will burn less brightly over the Los Angeles Olympic Games.

Id. at 684 (Pregerson, J., dissenting).

117. Sagen v. Vancouver Org. Comm. for the 2010 Olympic \& Paralympic Winter Games (2009), 98 B.C.L.R. 4th 141 (Can. B.C.). On December 22, 2009, the Supreme Court of Canada refused appellants' leave to appeal. Sagen v. Vancouver Org. Comm. for the 2010 Olympic \& Paralympic Winter Games, 2009 CarswellBC 3468 (Can. S.C.C.) (WL).

118. Sagen (2009), 98 B.C.L.R. 4th para. 21.

119. Id. para. 9.

120. Id. para. 56 .

121. See also U.S. Olympic Comm. (USOC) v. Intelicense Corp., 737 F.2d 263, 268 (2d Cir.), cert. denied, 469 U.S. 982 (1984) (stating that the Amateur Sports Act, a federal statute, "cannot be overborne by the terms" of IOC Charter, which "is not a treaty ratified in accordance with constitutional requirements"). 
laws, and Martin and Sagen, which, on the other hand, represent a deferential judicial view. For example, are Martin and Sagen simply aberrations from the traditional judicial view, or do these cases constitute the "camel's nose under the carpet" or the "thin end of the wedge," thereby signaling an increasing willingness of courts to defer to private international agreements such as the rules of international and Olympic sports organizations that may conflict with national law? ${ }^{122}$ If the latter, are there sound public policy reasons for this judicial approach, and what are the future implications for the development of global law based on other agreements between private parties (including those involving governmental participation or acquiescence)?

\section{B. CAS Awards, Lex Sportiva, and the Displacement of National Law}

The Code establishes the following rules regarding the substantive "law" to be applied by a CAS arbitration panel. In CAS ad hoc Division arbitration, the governing law is "the Olympic Charter, the applicable regulations, general principles of law and the rules of law, the application of which it deems appropriate." ${ }^{23}$ For CAS appeals arbitration proceedings, absent agreement of the parties, it is "the law of the country in which the federation, association or sportsrelated body which has issued the challenged decision is domiciled or

122. This is a current high-profile controversy, of particular interest to scholars studying the application of national and transnational civil liberties and personal privacy laws in an era of increasing globalization, which provides an illustrative example of the ongoing dispute concerning the primacy of national laws versus the need for uniform international sports rules and agreements. In Part II.A, we observed that the international antidoping regime has several features invasive of athletes' privacy interests. On January 1, 2009, WADA adopted a "whereabouts rule" requiring all elite athletes to provide three months" advance notice of their location one hour each day, seven days a week, from 6a.m.-11p.m., so they can be tested out-of-competition by WADA without any warning. European Union Sports Commissioner Jan Figel has demanded that WADA revise this rule to comply with European privacy laws because "WADA rules do not supersede [the] laws of countries." Raf Casert, EU Sports Chief Demands WADA Changes, Assoclated PREss, Apr. 27, 2009. In response, WADA president John Fahey claimed that doing so "could potentially undermine the fight against doping in sport." Id. In January 2010, a Spanish court rejected a Spanish professional cyclist's claim that the Union Cycliste Internationale (UCI) (the IF for cycling)'s whereabouts rule, which was based on WADA's rule, breached his individual rights guaranteed by the Spanish Constitution. See Press Release, Union Cycliste Internationale, The Appeal by Carlos Roman Golbano Is Rejected (Jan. 27, 2010), available at http://www. uci.ch/ (use "search" box, search "Golbano rejected" hyperlink) (last visited Nov. 8, 2010).

123. Arbitration Rules for the Olympic Games, COURT OF ARBITRATION FOR SPORT, art. 17, http://www.tas-cas.org/adhoc-rules (follow "Arbitration Rules for the Olympic Games" hyperlink) (last visited Sept. 11, 2010). 
according to the rules of law, the application of which the [CAS] Panel deems appropriate." 24

Despite having express authority to do so, the CAS rarely relies on national law other than Swiss law (the IOC, WADA, and most IFs are domiciled in Switzerland) to invalidate Olympic and international sports governing body agreements and rules. ${ }^{125}$ For example, recognizing the need for a uniform body of global sports law, CAS panels generally have refused to rule that athlete doping rules and sanctions violate the national laws of an athlete's home country. ${ }^{126}$ Similarly, in appeals arbitration resolving other types of disputes, the CAS generally has declined to apply national laws other than the domestic law of an international sports governing body's home country. ${ }^{127}$

The Swiss. Federal Code on Private International Law provides for judicial review of a CAS arbitration award by the SFT on very narrow grounds. ${ }^{128}$ The SFT is authorized to vacate an arbitration award if the CAS panel was constituted irregularly, erroneously held that it did or did not have jurisdiction, ruled on matters beyond the submitted claims, or failed to rule on a claim. ${ }^{129}$ An award also may be

124. Arbitration Code, supra note 68, r. 58.

125. On the other hand, CAS arbitrators have expressed a willingness to rely on (or to at least survey) national laws when developing a rule of law to govern a dispute that cannot be resolved solely by applying a sports governing body's internal rules. See, e.g., Arbitration CAS 2004/A/704, Yang Tae Young v. Int'l Gymnastics Fed'n, award of Oct. 21, 2004 (considering the extent to which courts have been willing to judicially review and interfere with a referee's application of the rules of the game or field of play decision).

126. See, e.g., Arbitration CAS 2007/A/1312, Adams v. CCES, award of May 16, 2008 (finding no violation of Ontario Human Rights Code); Arbitration CAS 2006/A/1149 and 2007/A/1211, World Anti-Doping Agency (WADA) Federación Mexican de Fútbol (FMF) \& Alvarez, award of May 16, 2007 at para. 35 (rejecting athlete's claimed violation of Mexican law); Arbitration CAS 2006/A/1 102, Eder v. Ski Austria, award of Nov. 13, 2006 (refusing to use Austrian law to invalidate challenged World Anti-Doping Code rules or their application to Austrian athlete by Austrian national governing body); Arbitration CAS 2005/A/951, Cañas v. ATP Tour, award of May 23, 2007 (finding no violation of Delaware, U.S. antitrust, or European Union law).

127. Arbitration CAS 2006/A/1110, PAOK FC v. UEFS, award of Aug. 25, 2006 (rejecting Greek football club's request to apply Greek law to club licensing dispute with UEFA).

128. See PIL, supra note 78 .

129. In $X$. (Cañas) v. ATP Tour, 4P.172/2006 (2007) (Switz.), ATF 133 III 235, translated in 1 Swiss INT'L ARB. L. REP. 65, the SFT vacated and remanded a CAS award because it violated an athlete's right to a fair hearing by not providing reasons for rejecting arguments that his doping sanction violated Delaware, U.S., and European Union laws. The SFT ruled that CAS arbitrators must discuss all of the parties' arguments in their legal analysis of the relevant issues in dispute, including claims that applicable national or transnational laws have been violated. The panel must explain "if only briefly" their reasons "so that the petitioner could be satisfied upon a perusal of the award that the arbitrators had 
vacated if the parties are not treated equally by the CAS panel, if a party's right to be heard is not respected, or if the award is incompatible with Swiss public policy. ${ }^{130}$

To date, the SFT has uniformly rejected all challenges to the substantive merits of a CAS panel's decision. ${ }^{131}$ A CAS award may be challenged on the ground that it is incompatible with Swiss public policy, but such a claim has not been successful. The SFT has explained that this defense "must be understood as a universal rather than national concept, intended to penalize incompatibility with the fundamental legal or moral principles acknowledged in all civilized states." ${ }^{132}$ The SFT has ruled that "even the manifestly wrong application of a rule of law or the obviously incorrect finding of a point of fact is still not sufficient to justify revocation for breach of public policy of an award made in international arbitration proceedings."133 It has characterized this standard as "more restrictive and narrower than the argument of arbitrariness. ${ }^{\prime 134}$

Because the "seat" of all CAS arbitrations is designated as Lausanne, Switzerland, regardless of the geographical location of the hearing, a CAS award is a foreign arbitration award in all countries except Switzerland. Thus, CAS arbitration awards require judicial recognition by national courts to be legally enforceable outside of Switzerland. The United Nations Convention on the Recognition and Enforcement of Foreign Arbitral Awards (New York Convention), a treaty to which the United States, Australia, and more than one hundred other countries are signatories, provides for judicial recognition and enforcement of foreign arbitration awards, including CAS awards, by national courts. ${ }^{135}$

considered all of his arguments which had objective relevance, even if it was to dismiss them ultimately." Id. at 98.

130. See PIL, supra note 78, art. 190. See generally Antonio Rigozzi, Available Remedies Against CAS Awards, in Sport GovernanCE, Football Disputes, DOPING AND CAS ARBITRATION (M. Bernasconi \& A. Rigozzi eds., 2009).

131. Rigozzi, supra note 130 , at $134-41$.

132. N., J., Y., W. v. Fédération Internationale de Natation (FINA), 5P.83/1999 (2d Civil Court, Mar. 31, 1999) at 779.

133. Id.

134. G. v Fédération Equestre Internationale, (1st Civ. Ct., Mar. 15, 1993) (translation) in DigEST OF CAS AwARDS 1986-1998, at 561, 574 (Matthieu Reeb ed., 1998).

135. United Nations Convention on the Recognition and Enforcement of Foreign Arbitral Awards, June 10, 1958, 21 U.S.T. 2517 [hereinafter New York Convention]; Abbas Ravjani, The Court of Arbitration for Sport: A Subtle Form of International Delegation, $2 \mathrm{~J}$. INT'L MEDIA \& ENT. L. 241, 251 (2009) ("CAS has had success in having its judgments that arise from contractual disputes enforced, while [International Court of Justice] judgments arising out of treaties often have trouble being enforced."). 
Article V(2)(b) of the New York Convention states that a national court may refuse to recognize and enforce an arbitration award if doing so "would be contrary to the public policy of that country." 136 Consistent with the SFT, U.S. courts have strictly construed the "public policy" defense and have uniformly recognized the validity of foreign sports arbitration awards, including CAS awards, if the parties had agreed in writing to be bound by it or participated in the arbitration proceeding. ${ }^{137}$

Judicial recognition and enforcement of CAS awards under the New York Convention has the potential to legitimize the development of a body of lex sportiva thereby supplanting conflicting national laws in 144 countries that have signed this treaty. ${ }^{138}$ The lex sportiva established by the collective body of CAS awards is accorded important legal international standing pursuant to the New York Convention's requirement that the integrity of foreign arbitral awards generally be respected and enforced by national courts. This is a very significant development, especially given the following factors: the monolithic global governing authority of IFs; required consent to CAS jurisdiction as a condition of a NOC's recognition by the IOC or athlete's eligibility to participate in Olympic and other international sports competitions; and potential conflicts with national laws that may provide greater substantive legal protection to individuals than are recognized by a CAS award. ${ }^{139}$

136. New York Convention, supra note 135, art. V(2)(b).

137. Slaney v. Int'l Amateur Athletic Fed'n (IAAF), 244 F.3d 580 (7th Cir.), cert. denied, 534 U.S. 828 (2001); Gatlin v. U.S. Anti-Doping Agency, Inc., No. 3:08-cv241/LAC/EMT, 2008 WL 2567657 (N.D. Fla. June 24, 2008). These cases are consistent with nonsports cases rejecting claims that a foreign arbitral award should not be enforced because it violates public policy. Indus. Risk Insurers v. M.A.N. Gutehoffnungshütte GmbH, 141 F.3d 1434, 1445 (11th Cir. 1998) (finding no "violation of public policy of the sort required to sustain a defense under . . . Convention"); Parsons \& Whittemore Overseas Co. v. Societe Generale de L'Industrie du Papier (RAKTA), 508 F.2d 969, 974 (2d Cir. 1974) ("Convention's public policy defense should be construed narrowly. Enforcement of foreign arbitral awards may be denied on this basis only where enforcement would violate the forum state's most basic notions of morality and justice."). But see Dynamo v. Ovechkin, 412 F. Supp. 2d 24 (D.D.C. 2006) (refusing to enforce Russian arbitration award finding that Alexander Ovechkin is contractually obligated to play for Moscow Dynamo during the 200506 hockey season and banning him from playing for any other club because Dynamo did not prove Ovechkin agreed in writing to arbitrate the parties' dispute).

138. Convention on the Recognition and Enforcement of Foreign Arbitral Awards, UNITED NATIONS TREATY COLleCtion (Sept. 9, 2010), http://treaties.un.org/pages/ participationstatus.aspx (follow "Chapter XXII" hyperlink; follow "l. Convention on the Recognition and Enforcement of Foreign Arbitral Awards" hyperlink) (listing countries ratifying the Convention).

139. The CAS does provide two important procedural rights to athletes, namely the right to be heard before an independent and impartial panel of arbitrators, and de novo review 
Gatlin v. United States Anti-Doping Agency, Inc., illustrates how international law may enable a CAS award to effectively displace otherwise applicable national laws of an athlete's home country by precluding a court from remedying their alleged erroneous interpretation or application by an arbitral tribunal. ${ }^{140}$ In Gatlin, a federal district court ruled it did not have jurisdiction to consider Justin Gatlin's claim that his four-year suspension imposed by CAS for a 2006 doping offense violated the Americans With Disabilities Act (ADA). ${ }^{141}$ In an arbitration proceeding held in the United States, the CAS panel determined that Gatlin's 2006 positive test for exogenous testosterone was his second doping offense (thereby subjecting him to an eight-year suspension pursuant to an IF's antidoping rule) because he previously tested positive for amphetamines in 2001 , which was his first doping violation. Gatlin asserted that characterizing his 2001 positive test, which resulted from taking prescription medication for his attention deficit disorder, as his first doping offense (even though the IAAF had restored his eligibility because he was taking it for a legitimate medical reason) violated the ADA, which the CAS panel rejected. ${ }^{142}$ However, the CAS panel reduced Gatlin's suspension to

of international sports governing body decisions, which is not constrained by national laws that would preclude a domestic court from providing the same scope of judicial review. See, e.g., Arbitration CAS 2008/A/11574, D'Arcy v. Australian Olympic Comm., award of July 7, 2008.

140. Gatlin, 2008 WL 2567657.

141. Id. However, U.S. domestic sports law generally does not provide athletes with greater legal rights than the developing body of lex sportiva. Strict liability for Olympic sports doping violations is permissible. See, e.g., Walton-Floyd v. U.S. Olympic Comm., 965 S.W.2d 35 (Tex. App. 1998). Monolithic private sports governing bodies may establish "take it or leave it" terms applicable to their members and athletes as a condition of eligibility to participate in competitive sports. Nat'l Collegiate Athletic Ass'n v. Tarkanian, 939 P.2d 1049 (Nev.), cert. denied, 522 U.S. 1028 (1997). U.S. courts refuse to allow state law to directly regulate the internal affairs of national sports governing bodies. See Flood v. Kuhn, 407 U.S. 258 (1972); Nat'l Collegiate Athletic Ass'n v. Miller, 10 F.3d 633 (9th Cir. 1993); Partee v. San Diego Chargers Football Co., 668 P.2d 674 (Cal. 1983). Moreover, the CAS's de novo review of international sports governing body rules and conduct exercised is more exacting than the very deferential arbitrary and capricious standard of review that U.S. courts generally exercise in reviewing domestic sports governing body rules and conduct. See generally Matthew J. Mitten \& Timothy Davis, Athlete Eligibility Requirements and Legal Protection of Sports Participation Opportunities, 8 VA. SPORTS \& ENT. L.J. 71 (2008).

142. Arbitration CAS 2008/A/1461, Gatlin v. USADA, award of June 6, 2008. In rejecting Gatlin's ADA claim, the CAS panel stated:

The Panel agrees with the IAAF's argument that there was no discrimination on the basis of a disability in this instance. The Panel is of the view that in order to constitute a violation, Mr. Gatlin must have been prevented from competing by virtue of his disability.... The Panel notes from Mr. Gatlin's own submissions that "Th7is $A D D$ affected his ability to focus in the classroom .... While Mr. Gatlin's disability admittedly put him at a disadvantage in the classroom, it in no way put 
four years based on its finding that the circumstances surrounding his 2001 doping offense constituted exceptional circumstances justifying a reduction from the rule's prescribed eight-year duration.

The court characterized the CAS panel's rejection of Gatlin's ADA claim as an "arbitrary and capricious" decision. ${ }^{143}$ The court found this error did not "rise to the level of moral repugnance" required by the New York Convention's public policy exception, which would justify judicial refusal to recognize a CAS award. ${ }^{144}$ Rather, the court effectively recognized and enforced the CAS arbitration award by refusing to permit Gatlin to relitigate its merits under the ADA. ${ }^{145}$ Expressing concern that its ruling "is quite troubling because ... United States Courts have no power to right the wrong perpetrated upon one of its citizens," the court observed that Gatlin's only judicial recourse was to request that the Swiss Federal Tribunal vacate the CAS award. ${ }^{146}$

Gatlin is consistent with the general refusal of U.S. courts to review the merits of claims resolved by arbitration awards. ${ }^{147}$ Of interest to comparative and arbitration law scholars is the apparent conflict between U.S. courts and the European Court of Justice (ECJ) regarding public international law and its relation to the state, specifically whether a final and binding arbitration award should preclude judicial reconsideration of the merits of the dispute it resolves. ${ }^{148}$

him at a disadvantage on the track. Indeed, until recently, he was the reigning

$100 \mathrm{~m}$ Olympic champion.

Id. para. 32.

143. Gatlin, 2008 WL 2567657, at *1.

144. Id.

145. The Gatlin court cited and relied upon Slaney v. Int'l Amateur Athletic Fed'n (LAAF), 244 F.3d 580 (7th Cir.), cert. denied, 534 U.S. 828 (2001), in which the United States Court of Appeals for the Seventh Circuit held that a U.S. athlete's state law claims seeking to relitigate the same doping dispute issues decided by a valid foreign arbitration award are barred by the New York Convention. It concluded, "Our judicial system is not meant to provide a second bite at the apple for those who have sought adjudication of their disputes in other forums and are not content with the resolution they have received." Id. at 591. See Weston, supra note 96, at 103-04 ("The United States has implicitly assigned the protection of the rights of its [athletes] to a private international tribunal seated in a foreign nation.").

146. Gatlin, 2008 WL 2567657, at*1-2. In April 2009, Gatlin settled his claims against all defendants (USOC, USA Track and Field, the United States Anti-doping Agency, and the International Association of Athletics Federations) on terms that were not publicly disclosed. Gatlin Settles Suit with USADA, USOC and Others, UNIVERSAL SPORTS, Apr. 14, 2009, http://www.universalsports.com/news/article/newsid $=284396 . \mathrm{html}$.

147. Thomas E. Carbonneau, The Revolution in Law Through Arbitration, 56 CLEV. ST. L. REV. 233, 239-41 (2008).

148. See Mitten, supra note 64, at 64-67. 
In Meca-Medina \& Majcen $v$. Commission of European Communities, the ECJ allowed two professional swimmers (a Spaniard and a Slovenian) to relitigate the merits of their claim that the Fédération Internationale de Natation (FINA)'s rule regarding the minimum level of nandrolone (a banned substance) in one's system sufficient to establish a doping offense violated European Union law. ${ }^{149}$ A CAS panel had previously rejected their contention, ${ }^{150}$ but reduced on other grounds the four-year suspension imposed on both swimmers by FINA, the Swiss-based IF for swimming, for testing positive for nandrolone during the 1999 World Cup swimming competition in Brazil. ${ }^{151}$ Rather than appealing the CAS panel's award to the SFT, the swimmers brought separate litigation alleging that the subject antidoping rule contravened European Union competition and freedom to provide services laws.

The ECJ ruled that European Union law applied because FINA's doping rules have the requisite effect on economic activity by regulating professional swimming. However, it rejected the swimmers' claims on their merits because they failed to prove that the rule regarding the minimum level of nandrolone sufficient for a doping violation was not disproportionate to FINA's legitimate objectives of ensuring that athletic competitions are conducted fairly and protecting athletes' health. However, it is remarkable that the ECJ did not consider that their European Union law claims had been expressly rejected by a prior CAS award, which the swimmers had agreed would be final and binding, or whether the fact that Switzerland, Spain, and Slovenia are parties to the New York Convention should preclude relitigation of their merits. Although the ECJ's decision effectively upheld the CAS award, Meca-Medina establishes precedent that permits future judicial challenges to the merits of CAS awards based on European Union law.

The potential for a CAS award to displace otherwise applicable national laws of an athlete's home country is also illustrated by an

149. Meca-Medina v. Comm'n of European Cmtys., 2006 E.C.R. I-6991.

150. Arbitration CAS 99/A/234 and 99/A/235, Meca-Medina \& Majcen v. Fédération Internationale de Natation Amateur (FINA), award of Feb. 29, 2000, paras. 4.4-.10; see also Arbitration CAS 2005/A/951, Cañas v. ATP Tour, award of May 23, 2007 (concluding that WADA antidoping rules and sanctions do not violate European law); Massimo Coccia, Applicable Law in CAS Proceedings: What To Do with EU Law?, in SPORT GOVERNANCE, FOOTBALl DISPUTES, DOPING AND CAS ARBITRATION, supra note 130 (discussing the relationship between CAS proceedings and EU law).

151. Arbitration CAS 2000/A/270, Meca-Medina \& Majcen v. Fédération Internationale de Natation (FINA), award of May 23, 2001. 
Australian court's decision in Raguz v Sullivan. ${ }^{152}$ Citing irregularities in an Australian NGB's application of the selection criteria, the CAS ruled that Raguz's selection for the Australian Olympic Team should be revoked and that another competitor should be selected instead. The New South Wales Court of Appeal rejected Raguz's request that it reverse the CAS ruling because the court lacked jurisdiction to do so. Curiously, the court did not base its ruling on the New York Convention, to which Australia is a party, or the federal legislation that implements it. ${ }^{133}$ Instead, it relied on nationally uniform arbitration laws enacted by Australian state legislatures. ${ }^{154}$ Raguz contracted with the Australian Olympic Committee to resolve any disputes by CAS arbitration rather than litigation in an Australian court, which is permitted by the uniform state arbitration laws for an arbitration "in a country other than Australia." 155 Because the seat of all CAS arbitrations is Lausanne, Switzerland, irrespective of where the arbitration proceeding is conducted, the court held that state arbitration law precluded it from considering the merits of Raguz's claims. ${ }^{156}$ The implication of this case is that, provided the parties to a CAS arbitration agreement properly invoke the Australian state arbitration laws, the lex sportiva being developed by the CAS has the potential to displace contrary Australian laws.

Because one of the primary objectives of establishing a private legal regime to resolve international sports disputes is to create a uniform body of lex sportiva that is predictable and evenly applied worldwide, ${ }^{157}$ it is problematic if CAS awards are not judicially reviewed pursuant to a generally accepted international standard. ${ }^{158}$

152. Raguz v Sullivan (2000) 50 NSWLR 236 (Austl.); see also Damian Sturzaker \& Kate Godhard, The Olympic Legal Legacy, 2 MELB. J. INT'L L. 241 (2001) (analyzing the Raguz decision).

153. International Arbitration Act 1974 (Cth) (Austl.).

154. Commercial Arbitration Act 1984 (NSW) s 40 (Austl.).

155. International Arbitration Act 1974 (Cth) s 3(1) (Austl.).

156. Raguz v. Sullivan (2000), 50 NSWLR 236, 257 (Austl.).

157. See, e.g., Arbitration CAS 2007/A/1298, Wigan Athletic FC v. Heart of Midlothian, award of Jan. 30, 2008, para. 64 (" $[1] \mathrm{t}$ is in the interest of football that solutions to compensation be based on uniform criteria rather than on provisions of national law that may vary considerably from country to country ....").

158. Yi, supra note 65, at 301-02 ("Olympic institutions, as a practical matter, simply cannot defend its myriad of decisions in the courts of every single member nation."). In 2005, a Swiss court in the canton of Vaud granted a preliminary injunction that suspended a CAS award upholding a two-year disciplinary suspension imposed by the International Cycling Union (UCI) on Danilo Hondo, a German cyclist, for his usage of a banned stimulant. Hondo owned a home in the canton of Vaud, and his lawsuit was based on an obscure Swiss law that permitted a Swiss resident to challenge judicially a Swiss arbitration award (e.g., a CAS award) in the canton in which he resided. He asserted that the UCI's strict 
Because Olympic and international sports competition occurs on a global basis and involves consensual (and often long-term) relationships, universally accepted rules and dispute resolution methods appear to be necessary. ${ }^{159}$

On the other hand, the displacement of sovereign national law by lex sportiva raises important issues worthy of scholarly study. ${ }^{160}$ For example, is a very limited scope of judicial review of CAS arbitration awards appropriate based on public policy considerations, including the need for an international legal regime that effectively protects all parties' respective rights and interests? Should an international treaty formally designate the CAS as the world court for sport with a permanent bench of judges, and would it likely function better than a

liability doping rules, which provided for an automatic two-year suspension for a first offense, violated Swiss law. Yi, supra note 65, at 337-39. The Appeals Chamber of the Court for the Canton of Vaud, as well as the SFT, ultimately upheld the CAS award, which required Hondo to serve a two-year suspension for his doping violation. Decision X [Danilo Hondo] v. AMA et consorts \& TAS, 4P.148/2006 of 10 Jan. 2007, ASA Bull. 2007, p. 569 (English translation available at $\mathrm{http}: / /$ translate.google.com/translate?hl=en\&sl$=\mathrm{fr} \& \mathrm{tl}=\mathrm{en} \& \mathrm{u}=\mathrm{http} \% 3 \mathrm{~A}$ $\% 2 \mathrm{~F} \% 2 \mathrm{Fwww}$.polyreg.ch\%2Fd\%2Finformationen\%2Fbgeunpubliziert\%2FJahr_2006\%2FE ntscheide_4P_2006\%2F4P.148_2006.html). Nevertheless, it is problematic to give a Swiss local court judicial authority to nullify a CAS award affecting Swiss residents based on its application of Swiss law; whereas, non-Swiss residents are required to seek vacation of a CAS award by the SFT on much narrower grounds.

159. See generally Mitten, supra note 64, at 64-67. In his book, How Soccer Explains The World, Franklin Foer hypothesizes that Americans' like or dislike of soccer, Europe's most popular sport, reflects their differing views regarding globalization. FRANKLIN FOER, HOW SOCCER EXPLAINS THE WORLD (2004). Those who like soccer believe "in the essential tenets of the globalization religion as preached by European politicians, that national governments should defer to institutions like the UN and WTO." Id. at 245. Those who do not believe "that America's history and singular form of government has given the nation a unique role to play in the world; that the U.S. should be above submitting to international laws and bodies." Id. Ironically, U.S. courts have taken a global view that facilitates a uniform body of lex sportiva; whereas, the ECJ's Meca-Medina decision threatens its worldwide uniformity and application. Although U.S. courts have recognized and enforced international arbitration awards that conflict with national law (albeit reluctantly), it raises the possibility that, in the future, U.S. judges may apply the New York Convention's "public policy" defense more broadly in an effort to protect U.S. athletes' rights under domestic law if other courts use national or transnational law to engage in de facto review of the merits of a CAS award.

160. A Greek law professor suggests that "public international law could lay down a regulatory framework for international sporting bodies." Dimitrios P. Panagiotopoulos, The Application of THE LEX SPORTIVA in the Context of National Sports Law, 9 J. COMP. L. 123, 131 (2008). He proposes that

the institutional autonomy of international sports federations and consequently the Lex Sportiva, and the corresponding jurisdictional order, should be placed under international scrutiny as to its legitimacy by what one might call a sports united nations. States must adopt an international sports charter to establish a truly international Lex Sportiva, a framework supporting the institutional autonomy and operation of international sporting bodies.

Id. at $139-40$ (footnotes omitted). 
private international arbitral tribunal? Although these are sportspecific issues, they may have broader implications for the resolution of conflicts between national laws and the developing body of decisions of international tribunals established by private agreement as well as the identification and establishment of a legal system for developing a global body of uniform law in particular areas that will be universally respected.

\section{SPORTS AS A HARBINGER OF FUTURE NATIONAL AND INTERNATIONAL LAW AND A FORUM FOR PUBLIC POLICY DEBATE}

Sports are an important cultural phenomenon in all countries of the world ${ }^{161}$ and have a unique ability to attract, entertain, inspire, and challenge a global populace. ${ }^{162}$ For example, in the United States and Australia (the authors' respective home countries), sports are a national obsession with millions of participants, spectators, and fans. Despite geographical distance and language barriers, international sports competitions (e.g., Olympics, FIFA World Cup, World Baseball Classic) and other transnational sports events (e.g., Commonwealth

161. See generally ALLEN GuTtMAnN, SPORTS: THE FIRST Five MiLlENNIA 1 (2004) (tracing the history and development of sports from preliterate to modern times and observing that "[s]ports are a human universal, appearing in every culture, past and present").

162. For example, people throughout the United States experienced powerful emotions upon learning that Central Washington University intercollegiate softball players Mallory Holtman and Liz Wallace, in an unprecedented act of sportsmanship, carried Western Oregon player Sara Tucholsky around the bases during a game in which she hit her first home run, but was unable to run the bases after seriously injuring her knee. "It gave gooseflesh to a phys-ed teacher in Pennsylvania, made a market researcher in Texas weak in the knees, put a lump in the throat of a crusty old man in Minnesota. It convinced a cynic in Connecticut that all was not lost." Thomas Lake, The Way It Should Be, SPORTS IlluSTRATED, June 29, 2009, at 56, http://sportsillustrated.cnn.com/vault/article/magazine/MAG1 157051/index.htm.

In Australia, an act of extraordinary sportsmanship has been immortalized in a large bronze statue in the sports district of Melbourne and named as the nation's finest sporting moment of the twentieth century. In 1956, John Landy, former 1500-meter world record holder and rival of Roger Bannister to be the first man to break the four-minute mark for the mile, was competing in the Australian mile championship in the lead-up to the 1956 Olympic Games in Melbourne. Ron Clarke, who would go on to "hold every world record [for distances] from two miles to twenty kilometres," fell after clipping the heel of another runner. Landy, who was following, tried to jump clear but with only partial success, and in the process trod on Clarke's arm with his spikes. As other runners passed by, Landy returned down the track to inquire as to Clarke's well-being and apologize. By then Clarke had regained his feet and Landy was satisfied the injury was not serious. Landy returned to the race, chased down the distant field and won! The delay had perhaps cost Landy a world record. Harry Gordon, John Landy, ATHLETICS AusTL. (2004), http://www.athletics.com. au/fanzone/hall_of_fame/john_landy. 
Games, Pan American Games) are commonplace. Sports have been envisioned as "a world language with many dialects."

Across geo-political boundaries, sports provide a forum for increased understanding, appreciation, and respect for mutually agreed-upon rules, fair play, and resolution of disputes among diverse cultures and societies. ${ }^{164}$ At present, more countries are members of the International Olympic Movement (205) than the United Nations (192). ${ }^{165}$ As Nelson Mandela, the former President of South Africa and recipient of the 1993 Nobel Peace Prize, has stated: "Sport has the power to change the world. It has the power to inspire. It has the power to unite people in a way that little else does.... It is more powerful than governments in breaking down ... barriers."1166

163. John J. MacAloon, Double Visions: Olympic Games and American Culture, in The OLYMPIC GAMES: ANCIENT AND MODERN 181, 183 (W. Lindsay Adams \& Larry R. Gerlach eds., 2002).

164. Roger I. Abrams, Cricket and the Cohesive Role of Sports in Society, 15 SETON HALL J. SPORTS \& ENT. L. 39, 40 (2005) ("Countries cannot be at play with one another and remain vigilant enemies, because at the very least there must be an agreement upon the rules for the sport's encounter. They compete in what may be termed a 'friendly spirit."').

165. As of June 2009, there are 205 National Olympic Committees. National Olympic Committee, OLYMPIC MOVEMENT, http://www.olympic.org/en/content/National-OlympicCommittee/ (last visited Nov. 8, 2009), while there are 192 members of the United Nations. Growth in United Nations Membership, 1945-Present, UNITED NATIONS, http:/l www.un.org/en/members/growth.shtml (last visited Nov. 8, 2010). Notably, Australian government policy has sought to foster cooperation in sport between Australia and other countries through the provision of resources such as facilities and the contribution of expert personnel. For example, the Australia Africa 2006 Sport Development Programme's

Active Community Clubs Initiative is funded by the Australian Agency for International Development-AusAID and is delivered by the Australian Sports Commission (ASC). The ASC is the federal agency that governs sport and sport development in Australia and through its International Relations division aims to assist, create and sustain opportunities for all people in the community to participate in, and benefit from, physical activity offered by multi-sport community-based clubs.

Rand Afrikaans Univ. Dep'T of Sport \& Movement Studies, An Impact Study on the Active Community Clubs Initiative, Final Report V (2006), http://www.ausport.gov.au/_ data/assets/pdf_file/0019/304912/2006_Impact_Study_Active_Community_Clubs.pdf.

166. LAUREUS: SPORT FOR GOOD FOUNDATION, 10 Year History of Laureus, TEN YEARS OF LAUREUS 2000-2010: HOW IT ALL BEGAN, Jan. 2010, at 5 (quoting Nelson Mandela award speech at the 2000 Laureus World Sports Awards (May 25, 2000)), http://www.laureus.com/ files/Foundation\%20Magazine_website.pdf. Danny Jordaan, the chief executive of the organizing committee for the 2010 FIFA World Cup, which was held in South Africa, stated:

Nelson Mandela struggled for, went to jail for and was released pursuing a vision of a country that would recognize every human being as equal, .... We want to move to a united future. What you need are projects that bind a nation, that carry a common and shared vision. I think that is what the World Cup will do.

Jere Longman, South Africa Under Microscope One Year Before World Cup, N.Y. Times, June 28,2009 , at SP1, available at http://www.nytimes.com/2009/06/28/sports/soccer/28 
Related to sports' cultural, economic, and political value, the combination of extensive media coverage and strong public interest in sports provides enormous power to convey educational messages to diverse global audiences (i.e., sports sell). Sports are a means to educate citizens about important social values and to encourage the public to pursue desirable standards of behavior. Positive values and ideals, which are intrinsic elements of sports or closely associated therewith, are promoted to the world's youth (and older generations) through sports participation or viewing. ${ }^{167}$ Sports competition also generates opportunities for academic discourse and public debate on social and ethical issues with broader implications and effects. ${ }^{168}$

soccer.html?_r=1\&scp=1\&sq=jere+longman+Microscope\&st=nyt (internal quotation marks omitted). Similarly, former Pope John Paul II said, "Sport is spread in every corner of the world, ... overcoming diversity of culture and nation." Steve Rushin, Heaven Helps Them, SPORTS ILLUSTRATED, May 2, 2005, http://sportsillustrated.cnn.com/vault/article/magazine/ MAG1111052/index.htm (internal quotation marks omitted). For example, Willye White, an African-American woman who was a member of four U.S. Olympic teams and competed in international track and field competitions in more than 150 countries, said:

Before my first Olympics, I thought the whole world consisted of cross burnings and lynchings .... The Olympic movement taught me not to judge a person by the color of their skin but by the contents of their hearts. Athletics was my flight to freedom ... my acceptance in the world. I am who I am because of my participation in sports.

Fred Mitchell, Olympian's Finest Work Came Long After Games, CHI. TRIB., Feb. 10, 2007, at 1 , available at 2007 WLNR 2665280 (internal quotation marks omitted).

167. The International Olympic Committee works closely with UNESCO to educate young people about "Olympic values" including the advancement of peaceful relations through sport. See, e.g., 6th World Forum on Sport, Education and Culture, "Educating the Now Generation," Busan, Korea, Sept. 25-27, 2008 [hereinafter Forum]. On June 16, 2009, President Barack Obama announced the formation of a permanent White House Office of Olympic, Paralympic, and Youth Sport to "promote the values of the Olympic Movement and [to] encourage increased youth participation in athletics." He stated, "Sports are an important way to instill values, judgment and teamwork in our nation's kids, and this new office reflects our commitment to giving all our children a chance to thrive." Lynn Sweet, Obama White House Putting Muscle Behind Chicago 2016 Olympic Bid, CHI. SUN-Times (June 16, 2009, 4:27 PM), http://blogs.suntimes.com/sweet/2009/06/obama_white_house_putting_musc.html (quoting President Barack Obama's Announcement of a New White House Office of Olympic, Paralympic and Youth Sport (June 16, 2009), available at http://www.whitehouse. gov/the_press_office/President-Obama-Announces-New-White-House-Office-of-OlympicParalympic-and-Youth-Sport/).

168. For example, developing science and technology creates an external means of enhancing individual athletic performance, which raises not only significant legal and ethical issues regarding sports competition, but also broader issues regarding the use of science to enhance human intellectual, physical, and psychological capabilities for other purposes. See, e.g., Gregor Wolbring, Oscar Pistorius and the Future Nature of Olympic, Paralympic and Other Sports, 5 SCRIPT-ED 139 (2008). 


\section{A. Domestic Sports Law's Influence on the Development of General National Laws and Public Policy}

Leading court rulings in a wide variety of legal fields have originated in the sports context. ${ }^{169}$ Thus, sports may be seen as influencing to some degree the development of general legal doctrine. A broad range of legal scholars will not find it difficult to identify a leading case in their respective areas of interest that involves sports; whether this is anything other than an entirely predictable consequence of the prevalence of sports in society could be a matter for scholarly inquiry. Perhaps sports are well represented because they often generate issues located at the fringes of legal principle requiring clarification or even development of new law by appellate courts (i.e., sports can make for hard cases)..$^{170}$

The commercialization of sports has given rise to numerous disputes requiring courts to apply several areas of general law (e.g., contract, intellectual property, labor, and antitrust laws) and to reassess their views about external regulation of the sports industry, which has led to the development of important legal precedent with much broader application. ${ }^{171}$ For example, in National Collegiate Athletic Ass'n (NCAA) v. Board of Regents, the United States Supreme Court established a widely used rule of reason framework for analyzing the legality of concerted restraints of trade under the U.S. antitrust laws. ${ }^{172}$ One scholar has aptly observed that $N C A A$ "makes it clear that the

169. Regarding U.S. law, one commentator has observed:

In federal law, antitrust and labor doctrine have been significantly shaped by cases originating in the sports industries. In addition, constitutional principles involving drug testing and search and seizure have been influenced by sports law cases. On the state level, important tort doctrine has been and will continue to be affected by disputes arising in the context of sports. Undoubtedly, other areas of the law will be similarly influenced by sports litigation.

Lazaroff, supra note 4, at 2-3. For example, several cases involving athletes have played a significant role in developing the scope of state law protection of publicity rights and First Amendment limits thereon. See, e.g., C.B.C. Distribution \& Mktg., Inc. v. Major League Baseball Advanced Media, 505 F.3d 818 (8th Cir. 2007), cert. denied, 128 S. Ct. 2872 (2008); ETW Corp. v. Jireh Publ'g, Inc., 332 F.3d 915 (6th Cir. 2003); see also Keith Sharfman, Valuation Averaging: A New Procedure for Resolving Valuation Disputes, 88 MINN. L. REv. $357,365-66$ (2003) (noting adoption and use of baseball final offer salary arbitration system to resolve joint venture valuation disputes).

170. Edward Grayson, International Reports 1992-England, ANZSLA NEwSLETTER, 1993, at 1, 7; Hayden Opie, From the Sideline-A Message from the President, ANZSLA NEWSLETTER, 1993, at 1, 2.

171. Hayden Opie \& Graham Smith, The Withering of Individualism: Professional Team Sports and Employment Law, 15 U. N.S.W. L.J. 313, 313-17 (1992).

172. NCAA v. Bd. of Regents, 468 U.S. 85 (1984). 
Sherman Act applies to nonprofit entities" and "signaled an increasing reluctance by the Court to reflexively rely on per se antitrust principles and a willingness to at least hear purported justifications for trade restraints even where competitor collaboration was involved."173

Similarly, the Australian High Court's 1979 landmark decision, $R$ $v$ Judges of the Federal Court of Australia; Ex parte Western Australian National Football League, Inc., construing a provision of the Australian Constitution conferring power on the federal legislature to make laws with respect to "trading corporations," which arose out of a sports-related dispute, has had significant implications regarding the development of Australian corporate law. ${ }^{174}$ By a narrow majority, the High Court ruled that a corporation's current activities, rather than the purpose for its formation, determined whether it is a "trading corporation." ${ }^{175}$ Two football leagues and one football club were formed as not-for-profit, community controlled corporations for the purpose of organizing or participating in sporting competitions. Because all three entities were sufficiently engaged in business activities in support of their sporting purposes (including the sale of tickets, media rights, advertising, and catering), the High Court held they constituted "trading corporations" within the terms of the Constitution. ${ }^{176}$

Whatever may be the degree to which sports cases are represented in leading judicial rulings, this feature of sports law is likely to retain an ad hoc or random character because the uncertainties of litigation are important determinants of which disputes and issues ultimately are resolved by appellate courts. Of greater significance for present purposes is the emerging capacity of sports to act as a catalyst for law reform and to provide a venue for public policy debate. We previously noted that sports have enormous power to convey educational messages to diverse global audiences because of its extensive media coverage and the public's strong interest in sports. ${ }^{17}$ Consequently, debates over social issues that occur in the context of

173. Lazaroff, supra note 4 , at 7-8, 15 .

174. AUSTRALIAN CONSTITUTION s 51(xx).

175. R v Judges of the Fed. Ct. of Austl.; Ex parte W. Austl. Nat'l Football League, Inc. (1979) 143 CLR 190.

176. Id. at 210-11 (Barwick CJ), 233-37 (Mason J, with whom Jacobs J agreed), 23940 (Murphy J). Implicit in this reasoning is a judicial conclusion that an organization's simultaneous pursuit of both sporting and business interests is not incompatible-a conclusion that courts may have been reluctant to reach at the height of the ethos of amateurism.

177. See Forum, supra note 167; Sweet, supra note 167. 
sports may have a profound effect on public and governmental attitudes on issues with wider application beyond sports. Thus, it is important that legal scholars closely monitor sports law developments and participate in sports-related policy debates and legal initiatives; otherwise, broader legal reform and/or public policy issues in their respective fields may become shaped or resolved without their timely input. ${ }^{178}$ Conversely, proponents of issues having wide social relevance may use sports as a venue for raising and advancing their views because of sports' capacity to draw attention to particular issues or grievances.

In 1994, David Halberstam, a respected sportswriter, observed:

[S]ports has been an excellent window through which to monitor changes in the rest of the society as we become more and more of an entertainment society. I do not know of any other venue that showcases the changes in American life and its values and the coming of the norms of entertainment more dramatically than sports. We can learn as much about race from sports as almost any subject and we can learn what the coming of big money does to players and to lines of authority more from sports than anything else. ${ }^{179}$

Halberstam stated that the St. Louis Cardinals' victory in the decisive seventh game of the 1964 World Series with four black players in the club's lineup "represented not just a larger slice of America, but a more just America." "180 One of those players was Curt Flood who later achieved legal fame as the unsuccessful plaintiff in Flood v. Kuhn, in which the Supreme Court affirmed Major League Baseball's common

178. In Australia, it is generally accepted that employers may test employees for their use of illicit drugs such as cocaine, amphetamines, and marijuana, and take preemptive disciplinary action for purposes of workplace safety. Beyond that, the usefulness of testing has been considered as less important than protection of employees' privacy interests. In 2005, that position was significantly affected when the Australian Football League (AFL) with the agreement of the Players' Association introduced testing for illicit drug use at any time of the year outside of competition including the players' private time. Australian Football League Illicit Drugs Policy, (Feb. 2005) (on file with authors). (The WADA Code prohibits illicit drugs but only during competition.) The action of the AFL received widespread attention in the news media and was greeted with approval by political leaders and the public but little scholarly attention from academics working in the fields of labor law and civil liberties. This lack of scholarly (and perhaps critical) evaluation and the willingness of such a high-profile group of employees to accept testing for illicit drugs by their employers during private time have established an arguably unchallenged and powerful precedent for employees in other industries.

179. David Halberstam, Sports as a Window of Social Change, SporTing News, May 23, 1994, reprinted in DAVID HALBERSTAM, EVERYTHING THEY HAD: SPORTS WRITING FROM DAVID HALBERSTAM 22, 27 (Glenn Stout ed., 2008).

180. Id. at 28 . 
law antitrust exemption. ${ }^{181}$ Flood's efforts to free himself and other baseball players of Major League Baseball's "reserve system" (which provided a club with perpetual rights to a player's services even after his contract expired) had parallels with the civil rights movement, and each drew support from and inspired the other ${ }^{182}$

Many nations outlaw racial abuse or vilification as an adjunct to antidiscrimination laws. However, Australia's racial vilification laws are of relatively recent origin. ${ }^{183}$ Before these laws were enacted, racial vilification by players and spectators was more or less tolerated as a tactic to distract an opponent. On April 17, 1993, during a match between the St. Kilda and Collingwood Football Clubs in the Australian Football League (AFL), an indigenous Australian who played for St. Kilda, Nicky Winmar, was racially taunted by the crowd of Collingwood supporters. ${ }^{184}$ St. Kilda was unexpectedly victorious and Winmar was instrumental in that success. Towards the end of the game when the result was certain, Winmar stood before the crowd, pulled up his shirt and pointed defiantly to his black skin. Images of this incident were carried by national news media and were probably instrumental in the passage of Australia's racial vilification laws. Another highly publicized incident of racial abuse of another indigenous AFL player, together with impending federal legislation, prompted the AFL to introduce rules and policies against racial and religious vilification, which included educational programs and a procedure for making confidential complaints and conciliation. ${ }^{185}$ Although not entirely free of criticism, the AFL's approach has been so successful that it is regarded as a model, and the AFL's strong stance has served to pave the way for wider public acceptance of the antivilification laws and the social policies they reflect. ${ }^{186}$

181. Flood v. Kuhn, 407 U.S. 258 (1972). For a detailed account of this litigation and its background, see SNYDER, supra note 8 . Major League Baseball's common law antitrust exemption was limited by the Curt Flood Act of 1998, which provides MLB players with the same antitrust law remedies as other major league players. 15 U.S.C.A. $\$ 26 \mathrm{~b}$ (c) (2009).

182. SNYDER, supra note 8, at 60-62, 115-16. However, some African-American civil rights groups "failed to make the connection between Flood's lawsuit and the freedom struggle." Id. at 115 .

183. In 1995, amendments to the federal Racial Discrimination Act specifically outlawed racial vilification. Racial Discrimination Act 1975 (Cth) s 18c (Austl.).

184. Ian Warren \& Spiros Tsaousis, Racism and Law in Australian Rules Football: $A$ Critical Analysis, 14 SPORTING TradiTIONS 27, 35-37 (1997).

185. Id. at 38-42.

186. See generally id:; Lawrence McNamara, Tackling Racial Hatred: Conciliation, Reconciliation and Football, 6 AUSTL. J. HUM. RTS. 5 (2000). 


\section{B. International Sports Law's Influence on the Development of Global Legal Norms and Policies}

In this Part, we observe that the rules and commercial arrangements of international and Olympic sports possess a unique capacity to spread legal norms worldwide because of the growing importance of international sports competition. International sports law, which includes the developing body of lex sportiva, illustrates that there are important areas of law in which globalization may create a need for worldwide uniformity (rather than balkanization by national law) and may be a harbinger of tomorrow-perhaps international harmonization of more laws (and the corresponding twilight of domestic law in those areas) as the world becomes more globalized. The potential of sports to drive international legal reform has only recently become evident, so our discussion will necessarily involve a degree of crystal ball gazing. To demonstrate our thesis, we will briefly consider two areas: intellectual property and anti-ambush marketing laws, and human rights laws. ${ }^{18}$

Before we do so, a general observation can be made about how international sports law may influence the evolution of national laws. It is possible that the developing body of lex sportiva created by CAS will influence judicial resolution of purely domestic sports industry disputes and the development of national sports law by having a transjudicial effect. It is a technique well known to the common law for courts to consider the opinions of foreign courts resolving similar issues, as well as international conventions and practice in the search for solutions to difficult problems. ${ }^{188}$ We suggest that it may be

187. Other possible areas for exploration include: extraterritorial enforcement of player contract rights and remedies, Boston Celtics Ltd. v. Shaw, 908 F.2d 1041 (1st Cir. 1990); internationalization of labor markets, Heather E. Morrow, The Wide World of Sports Is Getting Wider: A Look at Drafting Foreign Players into U.S. Professional Sports, 26 HOUS. J. INT'L L. 649 (2004); and the application of antitrust and competition laws to player restraints, Stephen F. Ross, Player Restraints and Competition Law Throughout the World, 15 MARQ. SPORTS L. REV. 49 (2004) (noting that despite different national competition laws, a uniform legal standard is developing regarding legality of player restraints); or internal league governance, Arbitration CAS 98/200, AEK Athens v. UEFA, award of Aug. 20, 1999 (applying Swiss and European Union competition law in rejecting a challenge to the UEFA rule prohibiting clubs with common ownership from both participating in the same Pan European championship soccer competition; although U.S. antitrust law "has limited precedential value" because of different structure of U.S. sports leagues, the CAS observes that it is similar to the Swiss and European Union legal standard and the result likely would be the same under U.S. law).

188. For example, some U.S. Supreme Court justices recently have relied upon foreign and international laws to support their interpretations of the U.S. Constitution. See, e.g., Grutter v. Bollinger, 539 U.S. 306, 344 (2003) (Ginsburg, J., concurring) (referencing the 
appropriate for national courts to consider, compare, and/or adopt CAS jurisprudence in resolving purely domestic sports law disputes. For example, perhaps a U.S. court will consider the Pistorius $v$. International Amateur Athletic Federation CAS award ${ }^{189}$ as well as the Supreme Court's PGA Tour, Inc. V. Martin ${ }^{190}$ ruling in a future Americans with Disabilities Act case by a disabled U.S. athlete claiming an American sports-governing body must modify its rules to enable him or her to participate in an athletic event.

\section{Intellectual Property and Anti-ambush Marketing Laws}

Intellectual property and anti-ambush marketing ${ }^{191}$ laws are the backbone of the broadcasting, merchandising, and sponsorship agreements that finance international sports competitions and generate several billion dollars. ${ }^{192}$ Not surprisingly, the IOC and IFs are increasingly careful to ensure that countries in which international sports competitions are held will accord a sufficient degree of legal protection to their intellectual property, as well as the contract and

International Convention on the Elimination of All Forms of Racial Discrimination and the Convention on the Elimination of All Forms of Discrimination Against Women); Lawrence v. Texas, 539 U.S. 558, 573 (2003) (citing European Court of Human Rights opinion finding laws prohibiting homosexual conduct invalid under the European Convention on Human Rights).

189. Arbitration CAS 2008/A/1480, Pistorius v. Int'l Ass'n of Athletic Fed'n, award of May 16, 2008. A CAS panel ruled that Oscar Pistorius, a South African athlete who is a double amputee, was eligible to run in IAAF-sanctioned track events with "Cheetah" model prosthetic legs. An IAAF rule prohibited the use of "any technical device that incorporates springs, wheels or any other element that provides the user with an advantage over another athlete not using such a device." The panel concluded that, because scientific evidence did not prove that Pistorius obtained a metabolic or biomechanical advantage from using the "Cheetah" prosthetic legs, his exclusion would not further the rule's purpose of ensuring fair competition among athletes.

190. PGA Tour, Inc. v. Martin, 532 U.S. 661 (2001).

191. 'The term 'ambush', 'parasitic' or 'piratical' marketing is used to describe a completely legitimate group of methods (if planned and implemented carefully) that a company may use in order to associate itself with major events of public interest, like the Olympic Games." George Avlonitis \& Sofoklis Ladias, Ambush Marketing and the Olympic Games "Athens 2004," in SPORTS LAW: IMPLEMENTATION AND THE OLYMPIC GAMES 380, 380 (Dimitrios P. Panagiotopoulos ed., 2005). Ambushers have been very successful in circumventing traditional intellectual property rights conferred by copyright and trademark laws so as to associate their products and services with major sports events at very little cost and in the process deprive official sponsors and suppliers of the full return on their financial support of those events. Because this activity threatens the long-term viability of major events, legislatures have enacted special anti-ambush laws.

192. For example, the IOC maintains an immense marketing program. The two key elements are broadcast and sponsorship revenues, the latter undertaken through the Olympic Partner Programme (TOP). See Olympic Marketing Fact File, OlYMPIC MovemENT, http:// www.olympic.org/Documents/fact_file_2010.pdf (last visited Nov. 6, 2010). 
licensing rights of broadcasters, sponsors, or merchandisers. This may involve anti-ambush laws that confer a greater level of legal protection than traditional national trademark and unfair competition laws that provide legal remedies only from infringement that creates a likelihood of consumer confusion regarding affiliation, sponsorship, or endorsement. ${ }^{193}$ The intense competition among potential host countries and cities for major events such as the Olympic Games and the FIFA World Cup ensures a seller's market, and the bid documents for major events invariably require high levels of legal protection for the sports organization's rights. As major international sporting events move around the globe, they often leave a legacy of intellectual property reform and related legal developments, which may be specific to the event or sports organization or perhaps have wider relevance. ${ }^{194}$

The prospect of being awarded the right to host a major international sports event may prompt countries that do not have advanced intellectual property law regimes to revise their laws and

193. See, e.g., NHL v Pepsi-Cola Canada, Ltd. (1992), 92 D.L.R. 4th 349 (Can. B.C. B.C.S.C.).

194. See generally Robin Jacob, Trade Marks and the Olympic Games Throughout the Years, 23 EUR. INTELl. Prop. Rev. 1 (2001); Christina Michalos, Five Golden Rings: The Development of the Protection of the Olympic Insignia, 3 INT'L SPORTS L. REV. 64 (2006). For a discussion regarding specific Olympic Games, see Atlanta 1996-Robert N. Davis, Ambushing the Olympic Games, 3 VILL. SPORTS \& ENT. L.J. 423 (1996); Stephen M. McKelvey, Atlanta '96: Olympic Countdown to Ambush Armageddon?, 4 SETon Hall J. SPORT L. 397 (1994); Sydney 2000-Christopher N. Kendall \& Jeremy C. Curthoys, Running Rings Around the Sponsors: The Sydney Olympics and "Ambush Marketing," 11 AuSTL. INTELL. PROP. J. 5 (2000); Salt Lake City 2003-Nöelle K. Nish, Comment, How Far Have We Come? A Look at the Olympic and Amateur Sports Act of 1998, the United States Olympic Committee, and the Winter Olympic Games of 2002, 13 SETON HALL J. SPORT L. 53 (2003), Anne M. Wall, The Game Behind the Games, 12 MarQ. SPORTs L. Rev. 557 (2002); Athens 2004-Stephen McKelvey \& John Grady, An Analysis of the Ongoing Global Efforts To Combat Ambush Marketing: Will Corporate Marketers "Take" the Gold in Greece?, 14 J. LEGAL ASPECTS OF SPORT 191 (2004); Beijing 2008-Anne M. Wall, Intellectual Property Protection in China: Enforcing Trademark Rights, 17 MARQ. SPORTs L. REV. 341 (2006), Stacey H. Wang, Great Olympics, New China: Intellectual Property Enforcement Steps Up to the Mark, 27 LoY. L.A. INT'L \& COMP. L. REV. 291 (2005); Vancouver 2010-Laura Misener, Safeguarding the Olympic Insignia: Protecting the Commercial Integrity of the Canadian Olympic Association, 13 J. LEGAL ASPECTS OF SPORT 79 (2002), Juda Strawczynski, Is Canada Ready for the Vancouver Winter Games? An Examination of Canada's Olympic Intellectual Property Protection, 62 U. OF TORONTO FAC. L. REV. 213 (2004); London 2012-Anna Marie Blakely, London Olympic Games and Paralympic Games Act 2006: Less Presumptive than the London Olympics Bill, 17 ENT. L. Rev. 183 (2006), Rachel Montagnon \& Joel Smith, Intellectual Property: The London Olympics Bill, 28 EUR. INTELL. PROP. REV. N11 (2006). 
policies. ${ }^{195}$ For example, the enactment of China's Regulations on the Protection of Olympic Symbols 2002 (PRC) ${ }^{196}$ in connection with the 2008 Beijing Olympic Games coincided with its national government's shift away from its previous reluctance to protect intellectual property rights. ${ }^{197}$ It has been suggested that India's hosting of the World Cup of Cricket in 2011 will necessitate a change in its government's attitudes regarding anti-ambush legislation. ${ }^{198}$ This process can also apply to developed countries, especially in regard to modernizing their copyright laws to protect the digital media that are so important to sports broadcasting. In addition, legal agreements concerning sports event digital media rights are likely to have significant broader implications. For instance, scholars interested in differences between European and U.S. intellectual property laws should monitor legal developments concerning sports event intellectual property rights, which are strongly influenced by both European-trained lawyers who represent European-based sports governing bodies such as the IOC as well as U.S. lawyers representing U.S. broadcasters and media companies. ${ }^{199}$

In some countries such as Australia and the United States, which have recently hosted Olympic Games, the level of protection accorded to the Olympic marks exceeds that generally provided by trademark laws in those countries. ${ }^{200}$ Given the success of international and

195. The award of a major sporting event to a developing nation (e.g., Seoul, Korea (1988 Olympic Games), Beijing, China (2008 Olympic Games), South Africa (2010 FIFA World Cup), Rio de Janeiro, Brazil (2016 Olympic Games)) indicates that the developing nation has a threshold level of sophistication in its legal system sufficient to manage such an event and hosting the event may stimulate further general development of its laws.

196. (奥林匹克标志保护条例) [Regulations on the Protection of Olympic Symbols] (promulgated by Decree No.345 of the State Council of the People's Republic of China on February 4,2002, effective as of Apr. 1, 2002), ST. CoUNCIL, Jan. 30, 2002 (China), available at http://en.beijing2008.cn/bocog/ipr/n214071828.shtml (last visited Sept. 10, 2010).

197. ARUl George Scaria, Ambush Marketing: Game within a GaMe 96-99 (2008); Wang, supra note 194, at 291.

198. SCARIA, supra note 197 , at 100.

199. See Nicola Lucchi, Intellectual Property Rights in Digital Media: A Comparative Analysis of Legal Protection, Technological Measures, and New Business Models Under EU and U.S. Law, 53 BUFF. L. REV. 1111 (2005).

200. Olympic Insignia Protection Act 1987 (Cth) s 36 (Austl.) (prohibiting, among other things, the unauthorized use of "Olympic expression[s]" for commercial purposes so as to suggest sponsorship of certain Olympic interests); Ted Stevens Olympic and Amateur Sports Act, 36 U.S.C.A. $\$ 220506$ (c) (2001) (prohibiting unauthorized use of Olympic marks "for the purpose of trade, to induce the sale of any goods or services, or to promote any theatrical exhibition, athletic performance, or competition"). 
Olympic sports in having host nations introduce anti-ambush laws, ${ }^{201}$ some have suggested that it is now time for a standardized international approach, perhaps though a UNESCO-sponsored convention. ${ }^{202}$ Even reforms that are specific to the event or sports organization may have significant wider impacts because major global corporate sponsors have the right to use the intellectual property associated with the sporting event and sports organization, thereby also benefitting from any enhanced legal protections. Given the perceived importance of stronger intellectual property laws for the growth of world trade, sport is a player that drives legal reform and economic growth. ${ }^{203}$

\section{Human Rights Laws}

The awarding of the rights to host a major sports event such as the Olympic Games or the World Cup of Football has come to be linked to some degree directly or indirectly to the human rights records of the bidders. For disadvantaged groups, the attention on their country by the world's news media can be an occasion for them to bring their circumstances to the notice of a much wider audience and perhaps embarrass their government into desirable action. Realistically, the capacity of international and Olympic sports to effect real change in this way is probably quite limited. The 1936 Olympic Games in Berlin represents a notable failure. Despite protests from the IOC and even the threat of a possible boycott, the Third Reich made only token concessions in its campaign of discrimination against Jewish people generally and in its policy of excluding them the German Olympic team. ${ }^{204}$ In the lead-up to and during the Beijing Olympic Games, China was the object of criticism in the world's news

201. For example, in the lead-up to the Sydney Olympic Games in 2000 and pursuant to obligations under the host city contract, Australia passed specific legislation to extend the protection afforded Olympic marks and to guard against ambush activity. Sydney 2000 Games (Indicia and Images) Protection Act 1996 (Cth) (Austl.); see also Jeremy Curthoys \& Christopher n. Kendall, Ambush Marketing and the Sydney 2000 Games (Indicia \& Images) Protection Act: A Retrospective, 88 MuRDOCh U. EleCTRONIC J. L. (2001), http://www. murdoch.edu.au/elaw/issues/v8n2/kendall82.html.

202. James A.R. Nafziger, The Future of International Sports Law, 42 WILLAMETTE L. REV. 861, 871-73 (2006).

203. Carsten Fink \& Carlos A. Primo Braga, How Stronger Protection of Intellectual Property Rights Affects International Trade Flows, in INTELLECTUAL ProperTY AND DEVELOPMENT 19-40 (Carsten Fink \& Keith E. Maskus eds., 2005).

204. Barbara J. KeYs, GlobalizING SpORT: NATIONAL RIVALRY AND INTERNATIONAL COMMUNITY IN THE 1930s, at 136-41 (2006); see also DUFF HART-DAVIS, HITLER's GAMES: THE 1936 OLYMPICS (1986). 
media over its policies of internet and local news media censorship and other human rights issues. ${ }^{205}$ Whether the legacy of the Games and the attendant international spotlight will include meaningful long-term change in China in response to these criticisms is hard to assess.

Rather than explore the links between hosting events and human rights, which are often examined in the numerous histories and evaluations of the Olympic Movement, we will briefly make some other observations that may be of interest to scholars. ${ }^{206}$ The evolving body of international sports law, particularly agreements among private parties, may create and protect individual rights that currently are not recognized in some countries, thereby advancing the legal protection of human rights worldwide. For example, the fifth Fundamental Principle of Olympism embodied in the Olympic Charter states, "Any form of discrimination with regard to a country or a person on grounds of race, religion, politics, gender or otherwise is incompatible with belonging to the Olympic Movement." ${ }^{207}$ In accordance with their contractual obligation to comply with the Olympic Charter's antidiscrimination provisions, each of the 205 NOCs has a legal duty to ensure no Olympic sport athlete in their respective countries is excluded from sports participation or discriminated against for "racial, religious or political reasons or by reason of other forms of discrimination."208 The rules of IFs also may incorporate similar protections of human rights, which NGBs are required to respect and include in their respective rules. In accordance with their contractual or membership rights, individual athletes may be able to require legally their respective NGBs to accord them a level of human rights protection not otherwise available in their home countries. For instance, an athlete or official from a country which offers little or no human rights guarantees who is denied selection to a

205. See, e.g., Jacquelin Magnay with Mary-Anne Toy, Propaganda Bureau Muzzles Chinese Press; Guide for Editors Tells which Issues Must be Avoided, THE AGE (Melbourne), Aug. 14, 2008, available at http://www.muzzles.com.au/muzzles-articles/2008/8/14/propagandabureau-muzzles-chinese-press/; Mary-Anne Toy, Games Undesirables Expelled from Beijing, THE AGE (Melbourne), July 12, 2008, http://www.theage.com.au/world/olympic-undesirablesexpelled-from-beijing-2008071 1-3dqj.html. (1992)

206. See, e.g., Allen GutTMAnN, THE Olympics: A History OF THE MODERn GaMeS

207. Olympic Charter, supra note 37,11 para. 5.

208. Id. at 83 r. 45(3). Another example is WADA's International Standard for Protection of Privacy and Personal Information, which establishes a minimum global standard that may provide more privacy protection to athletes than some countries' existing domestic laws. Protection of Privacy and Personal Information, WORLd ANTI-DOPING AGENCY, http://www.wada-ama.org/Documents/World_Anti-Doping_Program/WADP-IS-PPPI/ WADA_IS_PPPI_2009_EN.pdf (last visited Nov. 6, 2010). 
national team on discriminatory grounds might successfully challenge that decision in a CAS proceeding as a breach of the NGB's rules and lex sportiva, notwithstanding that domestic law is not infringed. An IF could take punitive measures against an NGB that fails to honor a CAS award, which might include suspension of its membership rights and authorization to enter athletes in international sports competitions, which provides a formidable enforcement mechanism that is perhaps more powerful than judicial compulsion.

An illustration of the effectiveness of international enforcement action based on private agreement can be found in the area of sports employment rights. FIFA's Regulations for the Status and Transfer of Players (Regulations) regulate a number of aspects of the employment of soccer players worldwide. In the event of dispute between club and player, the Regulations empower an internal FIFA body, the Dispute Resolution Chamber, to rule upon it and, if either party is dissatisfied, the CAS may arbitrate. If a club refuses to comply with the ruling of the Chamber or the CAS, it may be practically difficult or inconvenient for a player to enforce a favorable ruling in a court having jurisdiction over the club. As an alternative, a complaint may be made by the player against the club to the FIFA Disciplinary Committee, which is empowered to impose a range of penalties including loss of premiership points (possibly leading to relegation of the club to a lower division of competition) for the club's failure to comply with the ruling of the Chamber or the CAS. ${ }^{209}$ While these penalties do not directly enforce those rulings, the avoidance of such penalties serves as a powerful incentive to comply that, as a practical matter in the world of competitive sports, is far more likely to be more compelling, efficient, and faster than judicial enforcement.

Given the significant cultural and economic importance of sports globally, sports law may sow seeds that germinate into the increased national legal protection of human rights, a topic of interest to scholars who study international human rights law as well as the globalization of law.

\section{CONCLUSION}

The evolving law of sports has potentially broad implications for the development of international, comparative, and national law as

209. Statutes, FIFA arts. 57, 59 (Aug. 2009), http://www.fifa.com/mm/document/ affederation/federation/01/24/fifastatuten2009_e.pdf; see also FRANS DE WEGER, THE JURISPRUDENCE OF THE FIFA DISPUTE RESOLUTION CHAMBER 39 (2008). 
[Vol. 85:269

well as global dispute resolution, and these implications often are not recognized or carefully considered. The law of sports offers fertile ground for academic study by legal scholars as well as those who teach sports law courses or focus their scholarship on sports law issues. In addition, attorneys and judges need to be aware that judicial resolution of sports-related cases may provide the seed that germinates into jurisprudence with broader application and more widespread effects. It is our hope that this Article contributes to greater awareness of the importance of sports, not only as a worldwide cultural phenomenon and a significant part of our twenty-first-century global economy, but as a rich source of both international and national public and private laws as well as lessons for establishing, implementing, and enforcing global legal norms. 